Piśmiennictwo zakonne $w$ dobie staropolskiej, red. Magdalena Kuran, Katarzyna KaczorScheitler i Michał Kuran, przy współpracy Dawida Szymczaka, Łódź 2013.

\title{
Konferencja „Piśmiennictwo zakonne w dobie staropolskiej” — stenogram dyskusji
}

\author{
opracował Dawid Szymczak
}

\section{Czwartek, 4 listopada 2010 roku}

\section{OTWARCIE OBRAD}

Dr Michał Kuran (Uniwersytet Łódzki):

Witam Państwa na konferencji poświęconej piśmiennictwu zakonnemu w dobie staropolskiej. O wprowadzenie do obrad poproszę Panią Profesor Danutę Bieńkowską.

Prof. dr hab. Danuta Bieńkowska (Uniwersytet Łódzki):

Witam Państwa bardzo serdecznie; tym serdeczniej, że reprezentuję Katedrę Historii Języka Polskiego, której zainteresowania naukowe są bliskie pracom podejmowanym w Katedrze Literatury Staropolskiej, będącej gospodarzem naszego spotkania.

Na początku chcę wyrazić uznanie i pełną aprobatę dla organizatorów przede wszystkim za temat konferencji, który — parafrazując słowa z Kazania na dzień św. Katarzyny z Kazań świętokrzyskich — pobudza, ponęca i powabia. To znaczy, że ma w sobie duży potencjał, który dla naukowca jest bardzo ważny. W czym widziałabym ów potencjał? Wiemy dużo na temat roli, jaką odegrało duchowieństwo — zarówno księża diecezjalni, jak i zakonnicy — w rozwoju polskiej kultury, przede wszystkim piśmienniczej, tak okresu staropolskiego, jak i następujących po nim wieków. Wiemy, że gdyby nie klasztory i zakonnicy, którzy w cichości swoich skryptoriów tworzyli teksty — kazania, modlitewniki, apokryfy — polska literatura rozwinęłaby się dużo później. Wiemy, iż powstające w środowiskach duchownych dzieła naukowe, przybliżały Polakom kulturę europejską minionych wieków. Jest to sprawa oczywista. Wciąż jednak niewiele wiemy o zbiorach zgromadzonych w bibliotekach zakonnych. Dostęp do nich zawsze był ograniczony, bo mnisi bardzo strzegli swoich zbiorów, niechętnie je udostępniając. Mam nadzieję, że z referatów dowiemy się więcej o zawartości i wartości owych księgozbiorów. Tematy referatów wskazują, że będziemy mieli także okazję lepiej poznać życie zakonne mnichów i mniszek, tak odmienne od naszego, świeckiego.

Życzę Państwu owocnych obrad. Organizatorzy poprosili mnie, abym przewodniczyła dzisiejszym obradom, które niniejszym otwieram. Mamy do przerwy zaplanowane cztery referaty. Pierwszy jest referat Ojca Doktora Anzelma Szteinke Rękopisy doby staropolskiej małopolskiej prowincji reformatów w Bibliotece Gtównej Prowincji Franciszkanów Reformatów w Krakowie. Serdecznie zapraszam.

\section{REFERATY WYGŁOSZONE W SESJI POPOŁUDNIOWEJ}

o. dr Anzelm Szteinke OFM, Rękopisy doby staropolskiej małopolskiej prowincji reformatów w Bibliotece Głównej Prowincji Franciszkanów Reformatów w Krakowie

dr Anna Kapuścińska, Kapucyńska twórczość hagiograficzna w rękopiśmiennych zbiorach zakonnej biblioteki prowincjonalnej $w$ Zakroczymiu

dr Tomasz Stolarczyk, Biblioteki Braci Kaznodziejów w Gidlach, Łęczycy, Łowiczu, Piotrkowie Trybunalskim i Sieradzu w XVII wieku i ich zbiory

dr hab. prof. UŁ Andrzej Wałkówski, Pochodzenie kancelaryjne trzech dokumentów rycerskich dla klasztoru cystersów w Mogile z lat 1228-1231 
dr hab. prof. UŁ Maria Wichowa, „Humanitas Christiana” w poradniku medytacji Diega de Estella "O zgardzie świata i próżności jego" w ttumaczeniu Augustyna Kochańskiego

dr Katarzyna Kaczor-Scheitler, Idea zastosowania zmystów w medytacjach o Męce Pańskiej na przykładzie rękopisu przechowywanego w Archiwum Norbertanek Zwierzynieckich

Dr Magdalena Kuran (Uniwersytet Łódzki):

Mam pytanie do Ojca Anzelma. Czy rękopis Chryzostoma Dobrosielskiego jest gdzieś udokumentowany? Czy jest to podstawa jego ascetyczno-mistycznej pracy?

O. dr Anzelm Szteinke (Warszawa):

Jak znaczyłem na początku pisanej wersji mego obecnego wystąpienia, które tutaj nieco skróciłem ze względu na ograniczenia czasowe, moje opracowanie jako pierwsze posiada charakter wstępnego rozeznania rękopisu, w którym starałem się ustalić jego tematykę, autora albo przynajmniej czas powstania. W tym konkretnym przypadku jedynie wysunąłem przypuszczenie, że wspomniany rękopis Ch. Dobrosielskiego (Z. 39) „został później wykorzystany w dziełku opublikowanym”.

Dr Magdalena Kuran:

A te rękopisy Węgrzynowicza i Dobrosielskiego zostały przez Ojca zidentyfikowane na podstawie autografów?

\section{O. dr Anzelm Szteinke:}

Wszystkie posiadane przez nas rękopisy Antoniego Węgrzynowicza są podpisane lub zostały rozpoznane dzięki ustaleniu charakteru jego pisma.

\section{Dr Magdalena Kuran:}

Chciałam jeszcze zapytać o funkcję diariuszów z podróży. Czy powstawały na użytek wewnętrzny zakonu?

\section{O. dr Anzelm Szteinke:}

Wprawdzie bliżej zainteresowałem się tylko jednym z diariuszy podróżnych, ale przejrzałem wszystkie zachowane w naszym zbiorze. Na tej podstawie mogę powiedzieć, że powstały z myślą o kolejnych podróżach, czyli były swego rodzaju przewodnikami. Pierwsze podawały w zasadzie trasę podróży, a następne poszerzały zasięg informacji w zależności od zainteresowania ich autorów. Przestudiowałem dokładnie dziennik autorstwa Remigiusza Zawadzkiego, zastępcy prowincjała wielkopolskiego na kapitułę generalną w Rzymie w 1750 roku. Wygłosiłem na jego temat referat na konferencji naukowej zorganizowanej przez Instytut Historyczny Uniwersytetu Wrocławskiego, który następnie ukazał się drukiem w kolejnym tomie serii „Staropolski ogląd świata. Rzeczpospolita między okcydentalizmem a orientalizacją. Przestrzeń wyobrażeń" (t. 2, Toruń 2009, s. 87-96). Cały dziennik okazał się na tyle interesujący, że wspólnie z profesorem Bogdanem Rokiem z Wrocławia postanowiliśmy wydać go drukiem w oryginalnej wersji łacińskiej i polskim tłumaczeniu. Profesor Rok opublikował już kilka diariuszy, m.in. o. Juwenalisa Charkiewicza, bernardyna prowincji litewskiej na kapitułę generalną w Walencji w 1768 roku (Wrocław 1998).

\section{Dr Magdalena Kuran:}

Ojciec wspominał, że niewiele zostało rękopisów z zakresu gramatyki i retoryki. Czy to wynika z przykładania w zakonie mniejszej wagi do tych dziedzin wiedzy?

\section{O. dr Anzelm Szteinke:}

Moim zdaniem, ilość rękopisów z zakresu gramatyki i retoryki w omawianym zbiorze, nie upoważnia do takiej konkluzji.

Dr Anna Kapuścińska (Uniwersytet Szczeciński):

Do Pani Doktor Kaczor-Scheitler. Czy podejrzewa Pani, że anonimowa norbertanka znała Ćwiczenia duchowne Ignacego Loyoli? Bo nie do końca to wybrzmiało. W zależności od Pani odpowiedzi będę formułowała kolejne pytania.

Dr Katarzyna Kaczor-Scheitler (Uniwersytet Łódzki):

Tak, podejrzewam, że autorka mogła znać Ćwiczenia duchowne Ignacego Loyoli, choć to wyłącznie hipoteza. Jest to anonimowa norbertanka, zatem trudniej tu o pewne ustalenia. 


\section{Dr Anna Kapuścińska:}

Może warto by w takim razie spojrzeć na to pod tym kątem. U Ignacego Loyoli bardzo ważną rolę odgrywa pierwiastek racjonalny. Widać to bardzo dobrze w Rozmyślaniu o dwóch sztandarach. Fundamentem jest tu praca intelektu, który dokonuje świadomych wyborów poprzez tworzenie swoistego katalogu zysków i strat, będących owocem podjętej decyzji; człowiek wybiera armię Chrystusa lub szatana, kontempluje dlaczego, szuka argumentów za i przeciw. Natomiast u norbertanek większa jest chyba rola elementów emocjonalnych, co oczywiście nie wyklucza Pani tezy. Być może przewaga emocjonalności związana jest z kobiecym przeżywaniem Męki Chrystusa. U Loyoli mamy wręcz retoryczne procedury, wszystko zakorzenione jest bardzo mocno w argumentacji. Wolę pobudzamy poprzez intelekt i emocje, ale nie przez same emocje.

Dr hab. prof. UŁ Krystyna Płachcińska (Uniwersytet Łódzki):

Szokujące, swoją drogą, jest to, co nazywa się właściwym zastosowaniem zmysłów — kiedy słyszymy o smakowaniu krwi, o wąchaniu krwi.

Dr Jacek Kwosek (Uniwersytet Śląski):

Nie przeciwstawiałbym tak bardzo sfery emocjonalnej i sfery racjonalnej. To, co da się racjonalnie przedstawić z pomocą argumentów za i przeciw, można też przekuć na formę obrazową. Ćwiczenia duchowne zachęcają do wizualizowania. Nawet jeżeli tam procedura jest racjonalna, to sam fakt, że jest wizualizacja, skłania do emocji. Natomiast, co się tyczy kobiecego przeżywania, słuchając Pani referatu, przypominały mi się motywy z librett kantat Jana Sebastiana Bacha. Tam też pojawiają się tego rodzaju motywy i nie dziwota, bo przecież są to motywy charakterystyczne dla tego typu problematyki.

Dr hab. prof. UŁ Maria Wichowa (Uniwersytet Łódzki):

Do referatu pani Kasi. Słuchałam go z przyjemnością. To jest kopalnia wiadomości o pewnym sposobie komunikowania się. Na ogół jest tak, że autor przekazuje jakąś myśl odbiorcy. A tu Pani ma teksty, w których odbywa się wewnętrzna rozmowa Pana Boga z człowiekiem, czyli inny kierunek komunikacji. Ja dostrzegam w literaturze staropolskiej nurt, który jest słabo opracowany. To, o czym Pani mówiła —o przekazie wewnętrznej rozmowy Boga z człowiekiem, o różnych sposobach wizualizacji — na terenie i literatury religijnej, i w znacznie większym stopniu na tle literatury świeckiej jest czymś, co nazywam umownie teatralizacją. Przemawia się do czytelnika, skłaniając go do tego, by włączył zmysły, aby odbiór był bardziej intensywny. Wspominany w moim referacie ks. Mateusz Ignacy Kuligowski wielokrotnie w swoich przekładach Heraklita i Demokryta dokonał adaptacji dwu poematów ks. Piotra Besseusza i trudno mi powiedzieć, czy to jest w wersji francuskiej, ale w polskim przekładzie wielokrotnie buduje sceny parateatralne. Wyraźnie mówi, że pojawia się ktoś na scenie, kogo mamy sobie wyobrazić i ten ktoś wygłasza jakąś kwestię. Widzę, że w literaturze medytacyjnej jest kopalnia informacji umożliwiająca wyjaśnienie tego zjawiska. Literatura przedmiotu w zasadzie tego nie dostrzega.

A jeśli idzie o sprawy emocjonalne, to ja bym tłumaczyła tym, że czytało się po prostu św. Augustyna. I to jest ten wpływ na kontemplację i medytację emocjonalną. Św. Ignacy daje inną wykładnię, inny sposób zgłębiania tajemnicy doskonalenia się wewnętrznego. Wtedy było to bardzo powszechne, ale przecież z założenia zakonnicy tego zgromadzenia powinni rozsmakowywać się, rozczytywać w pismach św. Augustyna. Wydaje mi się, że to byłaby odpowiedź na to, dlaczego w tego typu medytacjach dochodzi do głosu w większym stopniu pierwiastek emocjonalny niż zmysłowy.

Dr Krystyna Krawiec-Złotkowska (Akademia Pomorska):

Niejako ad vocem do tego, co Pani Profesor powiedziała. Jeżeli chodzi o sposób przeżywania, to nie należałoby tak radykalnie kategoryzować czy rozdzielać na „kobiece” i „męskie”. Mamy piękne Emblematy Zbigniewa Morsztyna, gdzie Oblubienica i Oblubieniec są uczestnikami tego samego dialogu. Słuchając referatu Pani Doktor, te emblematy nieustannie mi się przypominały. Poza tym, sensualizm w poezji baroku jest czymś prawie naturalnym i to, co dzieje się w sferze intelektualnej, przekłada się na wartości emocjonalne i próbę dążenia do perfekcji oraz przeżywania doskonałego. Intelekt wspiera emocje i widać to nie tylko w medytacjach, ale też w poezji metafizycznej. 
Dr Radosław Rusnak (Uniwersytet Warszawski):

Chciałbym odnieść się zarówno do referatu Pani Profesor Wichowej, jak i do referatu Pani Doktor Kaczor-Scheitler.

Pani Profesor traktuje polskie tłumaczenie Augustyna Kochańskiego niejako na tym samym poziomie, co jego hiszpański pierwowzór. Czy jednak nie mamy w tekście jakichś uwag tłumacza odnoszących się do pierwowzoru, które mogłyby świadczyć, iż tłumacz jest kimś, kto świadomie przyswaja tekst polskim odbiorcom? Czy można wychwycić jakieś różnice w traktowaniu kwestii takich jak dignitas christia$n a$, jeśli chodzi o grunt hiszpański i polski, czy też jest to pewne uniwersum, jakie tworzą zgromadzenia monastyczne w krajach katolickich. Czy można zaryzykować tezę, iż najbardziej aktywne były wówczas kanały łączące poszczególne klasztory? Stąd natłok adaptacji z języka hiszpańskiego na polski.

Natomiast jeśli chodzi o ostatnie z wystąpień, to, odnosząc się do kwestii emocjonalnego traktowania Męki Pańskiej, zastanowiło mnie wyłowienie z tłumu obserwujących Matki Bożej i zwrócenie uwagi na Jej sposób przeżywania sceny. Maryja jest stałą obserwatorką w różnych momentach tej medytacji. Czasem dochodzi do podwójnej sceny przeżywania - dusza obserwuje Chrystusa, ale też dusza obserwuje Maryję obserwującą Chrystusa. Czy potwierdza Pani moją intuicyjną refleksję, że Matka Boża jest szczególnie obecna w tych rozważaniach i czy ta obecność jest programatorem odczuć duszy, do której zwraca się autorka? I jeszcze jedno — ja miałbym opory przed odwoływaniem się do Całunu Turyńskiego, jeśli chodzi o wygląd Jezusa.

\section{Prof. dr hab. Danuta Bieńkowska:}

Mam pytanie do profesora Wałkówskiego. Czy w swoim postępowaniu metodologicznym próbował Pan sięgać do dokumentów z innych terenów i środowisk? A pytam dlatego, bo o ile przekonuje mnie dociekanie pochodzenia w oparciu o płaszczyznę graficzną, o tyle nie przekonuje mnie argumentacja w oparciu o płaszczyznę stylistyczną. Są to dokumenty należące do stylów administracyjnych, a jak wiadomo, te style mają charakter uniwersalny. Wobec tego stwierdzenie, że te formuły się powtarzają, to nie jest specyfika środowiska cysterskiego, ale może to być sprawa uniwersalna. Zatem dobrze byłoby sięgnąć do dokumentów z innych środowisk na zasadzie próby konfrontacji, która potwierdziłaby, że jest to sprawa stylistyki tekstów urzędowych. Mówię to na podstawie obserwacji stylistyki rot sądowych, które powstawały w różnych czasach i środowiskach. Pomimo tego, jest w nich powtarzalność formy.

Dr hab. prof. UŁ Andrzej Wałkówski (Uniwersytet Łódzki):

Od strony warstwy stylistycznej dokument średniowieczny można porównać do budowli z klocków. Tych klocków było bardzo dużo pod względem kształtu i koloru, a każdy z nich stanowił jedną z wersji formuły urzędowej. Dobór ich zależał od dwóch rzeczy: od środowiska pisarskiego (skryptorium, kancelaria) i od indywidualnego osobnika, który pewne formuły preferował, a innych nie. W przypadku moich badań, jeśli chodzi o płaszczyznę porównawczą, to biorąc, od doktoratu, dokumenty dwóch kancelarii śląskich - Henryka Grubego i Bolesława Rogatki (razem ok. 160 dokumentów) — następnie biorąc pod uwagę pracę habilitacyjną o skryptoriach cystersów filiacji portyjskiej na Śląsku (wszystkich dokumentów przebadanych było około pięćset), możemy wyróżnić w sposób wyraźny stylistykę ich formularza. Dotyczy, to zarówno środowisk ich powstania (kancelarie, skryptoria) jak i osób, które redagowały poszczególne pisma. Na pytanie: czy nie było uniwersalizmu schematycznego w postaci ksiąg formularzowych, co powoduje, że pod względem formuł i stylistyki dokumentu nie można przyporządkować go do tego czy innego środowiska lub osobie redaktora - udzielono już odpowiedzi. Badaczka ze Szczecina, Pani Doktor Agnieszka Gut ${ }^{1}$ udowodniła, że owe księgi formularzowe dla dokumentów powstających od dwunastego do pierwszej połowy czternastego wieku nie istniały. Różnorodność stylistyczna poszczególnych formuł jest tak przeogromna, że gdyby one rzeczywiście były, to byśmy tej różnorodności nie mieli. Ludzie funkcjonowali w kręgach, gdzie pewne zwroty były w użyciu ze słuchu i dany osobnik mógł dobrać sobie taki schemat formuł tak, że można wskazać, że to on redagował konkretny dokument. W przypadku kancelarii świeckich, gdzie akurat notariusze występują często imiennie, możemy przyporządkować im

\footnotetext{
${ }^{1}$ A. Gut, Formularz dokumentów książat zachodniopomorskich do połowy XIV wieku, Szczecin 2002, s. 246.
} 
nie tylko rękę pisarską, ale nawet stylistykę dokumentów. W przypadku formularza dotyczy to nawet tych dokumentów, których oryginały nie dochowały się. Powstała już na ten temat olbrzymia literatura. Jak widać, według schematu tekstu można wskazywać na środowisko powstania, a nawet na osobę, która redagowała dokument. Dla przykładu, sławny układ z 1249 roku księcia Bolesława Rogatki o przekazaniu Lubusza wraz z ziemią lubuską arcybiskupowi Magdeburga Wilbrandowi w zamian za pomoc wojskową. Mówi się, że Bolesław Rogatka kupczył ziemiami polskimi, a to akurat wyglądało zupełnie inaczej. Dokument ten był pod względem stylistyki ewidentnie zredagowany w kancelarii biskupów magdeburskich. A zatem książę otrzymał właściwie gotowy tekst i mógł go tylko przyjąć lub odrzucić. Odrzucić nie mógł, gdyż jeśli przyjrzymy się jego sytuacji militarnej i politycznej, to był on zagrożony wojną na dwa fronty². Są w średniowieczu dwie flagowe kancelarie: cesarska i papieska, których stylistyka natychmiast rzuca się w oczy, już choćby sztandarowy zwrot Stolicy Apostolskiej Servus servorum Dei. Istniały zatem pewne zwroty, które funkcjonowały w konkretnych środowiskach i ludzie tam piszący je wybierali. O istnieniu pewnych schematów właściwych środowiskom mówił znany polski satyryk i rysownik, Szymon Kobyliński. Opowiadał, że w którejś z redakcji czasopism satyrycznych w czasach wojny amerykańsko-wietnamskiej zrobiono zebranie satyryków, gdzie powiedziano im, że Amerykanie użyli broni biologicznej i że należy na ten temat stworzyć jakieś rysunki z komentarzem. Satyrycy rozeszli się do domów, żaden z nich nie kontaktował się z pozostałymi, a następnego dnia większość z nich przyniosła rysunki, gdzie stoi probówka na lawecie armatniej i obok żołnierz amerykański z okrzykiem „Bakteria pal!” Żyjemy w pewnych schematach werbalnych i niewerbalnych. Niemal tak samo było w przypadku anonimowych zakonników w średniowiecznych skryptoriach. Nie wiem, czy przekonałem Panią Profesor, ale zgodzę się co do jednego - używając osiągnięć grafologii, porównanie ręki pisarskiej jest rzeczą idealną. Do dziś zachowało się 40-50\% oryginalnych dokumentów średniowiecznych. W przypadku badanych przeze mnie dokumentów, zachowało się ich niemalże 100\% (Mogiła). Niestety, wiele z nich spisały unikatowo występujące ręce. W tym układzie musiałem badać pokrewieństwo graficzne szkoły mogilskiej i macierzystego wobec niej Lubiąża w powiązaniu ze stylistyką tekstu dokumentów. Nawiasem mówiąc, wpływy Lubiąża na Mogiłę opracowałem kiedyś w osobnym artykule 3 . To tyle.

\section{Dr hab. prof. UŁ Maria Wichowa:}

Pan Doktor Rusnak postawił kwestię, że traktuję adaptację na takim samym poziomie, co oryginał. Może powiem, jak wyglądała recepcja tej książki w Europie. To wcale nie było tak, że pracę tłumaczono z hiszpańskiego. Dzieło powstało w Hiszpanii pod nadzorem Świętej Inkwizycji i jeśli czytamy tekst polski, w którym nie ma najmniejszych napomknień do realiów Kościoła hiszpańskiego, to z założenia mamy do czynienia z tekstem o wymowie uniwersalnej. Znaczenie tej nauki dostrzeżono natychmiast, bo krótko po opublikowaniu hiszpańskiego tekstu przetłumaczono go na języki europejskie. Polski tekst powstał na bazie tekstu łacińskiego, a łaciński powstał na bazie przekładu włoskiego. Powstawały różne przekłady: angielski, francuski i niemiecki. W Anglii obecnie są bardzo ożywione badania nad angielską wersją. Bibliografia hiszpańska wskazuje tłumaczenia, jednak o polskiej wersji nie było mowy. Hiszpańscy badacze uznają wszakże fakt jej istnienia. Tekst włoski powstał pod wpływem Hieremiusza Foreste. Tekst łaciński sporządził Piotr Burgund, jezuita. Z łaciny na polski przełożył Augustyn Kochański — na druku widnieje formuła „za dozwoleniem Starszych”, a zatem cały czas była tu kwestia cenzury i poprawności doktrynalnej. Należy wobec tego traktować wersję polską jako wypowiedź uniwersalną, którą Kościół zaaprobował i która była traktowana jako rodzaj propagandy religijnej, propagowania idei de contemptu mundi. Należałoby przyjąć, że inaczej traktuje się teksty literackie, a inaczej teksty użytkowe. Tekst, o którym mówię, należy do tej drugiej kategorii. Jeśli poczytamy prace teoretyczne o komunikowaniu

\footnotetext{
${ }^{2}$ A. Wałkówski, Umowa księcia Bolesława II Rogatki z arcybiskupem magdeburskim Wilbrandem z 20 kwietnia 1249 roku, [w:] Studia Zachodnie, red. J. Benyskiewicz, Zielona Góra 1992, s. 25-35.

${ }^{3}$ A. Wałkówski, Podobieństwa w praktyce kancelaryjnej klasztorów cysterskich w Mogile i Lubiążu do końca XIII wieku, [w:] Pelplin. 725 rocznica powstania opactwa cysterskiego. Kulturotwórcza rola cystersów na Kociewiu, red. D. A. Dekański i in., Pelplin 2002, s. 107-125; zob. w tej sprawie tenże, Dziedziczenie zwyczajów pisarskich w zakonach na przykładzie ślaskiej gatęzi filiacyjnej cystersów z Pforty, [w:] Formuła. Archetyp. Konwencja w źródle historycznym, red. A. Gurak i K. Skupieński, Lublin 2006, s. 99-113.
} 
się poprzez literaturę, to tam wyraźnie jest powiedziane, że traktuje się te teksty jako uniwersalne formy przekazywania nauki i tak właśnie widziano to w dawnej Polsce. Chodziło właśnie o uniwersalną naukę Kościoła, rozprzestrzeniającą się w całej Europie.

\section{Dr Radosław Rusnak:}

Spodziewałem się, że w tekście użytkowym może być mało uwag autotematycznych od tłumacza, ale myślałem, że może pojawiło się coś w rodzaju przedmowy, w której powiedziane byłoby parę słów o sensie adaptowania czegoś, co powstało w kręgu katolickim, jednak w zupełnie innej rzeczywistości.

Dr hab. prof. UŁ Maria Wichowa:

Wyraźnie podkreślam, że idzie o uniwersalną wymowę i że tłumacz starał się oddać taki właśnie sens. Druga sprawa, że oni wszyscy byli znakomicie wykształceni pod względem retorycznym i tłumacz właściwie wszystkie rozwiązania przenosił na grunt polski. Retoryka to międzynarodowa umiejętność.

\section{Dr Katarzyna Kaczor-Scheitler:}

Chciałabym odnieść się do wypowiedzi Pani Doktor Anny Kapuścińskiej. Rzeczywiście, pierwiastek emocjonalny da się zaobserwować w medytacjach anonimowej autorki, ale myślę, że jest to też specyfika duchowości zakonów żeńskich. Natomiast jeśli chodzi o Ćwiczenia duchowne Loyoli, na pewno są w nich widoczne pierwiastki racjonalne. Ignacy Loyola pisał o współdziałaniu trzech władz duchowych: pamięci, rozumu i woli. Podkreślał, że pamięć przypomina treść danej prawdy, rozum rozważa i wyciąga wnioski, natomiast wola wzbudza odpowiednie uczucia.

Jeśli chodzi zaś o głos Pani Profesor Wichowej, nie wykluczam, że anonimowa autorka tego rękopisu korzystała z pism św. Augustyna. Inna siedemnastowieczna norbertanka, Teresa Petrycówna, będąca autorką medytacji, odwoływała się do dzieł Ojców Kościoła, w tym św. Augustyna, św. Bonawentury, św. Bernarda z Clairvaux. Istnieje zatem prawdopodobieństwo, że anonimowa autorka wskazanych medytacji korzystała także, zapewne za pośrednictwem nieujawnionych kompendiów, z myśli Ojców i Doktorów Kościoła, między innymi św. Augustyna.

Odwołując się do głosu Pana Doktora Rusnaka, mogę powiedzieć, że spośród pięćdziesięciu medytacji tylko w trzech pokazany został wizerunek Maryi. Rzeczywiście, w tych rozważaniach jest Ona szczególnie obecna. Autorka rozmyślań, chcąc pokazać sposób przeżywania przez Maryję sceny ukrzyżowania Chrystusa, odniosła się nie tylko do Ewangelii św. Jana, ale także do różnych źródeł apokryficznych. Uwydatniła również rolę adepta medytacji, który obserwując Maryję przeżywającą sceny związane z męką Jej Syna, nakłaniany jest do współodczuwania Jej bólu.

\section{Dr Anna Kapuścińska:}

Czy dostępne są jakiekolwiek katalogi biblioteki norbertanek? Czy można w jakikolwiek sposób odtworzyć ich księgozbiór? Statuty zakonne nakazywały zresztą, aby posiadano odpowiedni księgozbiór. Gdyby taki indeks był dostępny, to wydaje się pewne, że musiałby zawierać podstawowe pisma patrystyczne. Można by także poszukać, czy dysponowano jakąkolwiek — pełną bądź skróconą — wersją Ćwiczeń duchownych.

\section{Dr Katarzyna Kaczor-Scheitler:}

Archiwum Norbertanek Zwierzynieckich gromadzi wiele cennych starodruków i rękopisów, które są skatalogowane. W jego posiadaniu znaleźć można wiele rozpraw ascetyczno-mistycznych, pisma Ojców i Doktorów Kościoła, a także Ćwiczenia duchowne Ignacego Loyoli.

\section{Piątek, 5 listopada 2010 roku}

\section{REFERATY WYGŁOSZONE W SESJI PRZEDPOŁUDNIOWEJ}

dr Radosław Rusnak, Uwagi na marginesie edycji bazyliańskiego poematu „O zabiciu Mtodzianków” mgr Dawid Szymczak, Piotr Skarga jako historyk Kościoła wschodniego. Wstęp do problematyki

dr Krystyna Krawiec-Złotkowska, Jak „poruszał” i „oświecat” rozum człeczy kaznodzieja z Grójca?... Konstrukcje retoryczne w kazaniu „Na dzień s. Marcina biskupa” 
dr Halina Rusińska-Giertych, Repertuar wydawniczy tłoczni zakonnych — na przykładzie Drukarni Jezuickiej we Lwowie

\section{Dr Jacek Kwosek:}

Pierwsze pytanie jest natury ogólnej: skąd wiadomo, czy „grecy” się oddzielili od łacinników, czy odwrotnie? Czy na takie pytanie w ogóle jest możliwa odpowiedź udzielona przy pomocy metodologii nauk historycznych? Za tym idzie następna rzecz: czy Piotra Skargę należy traktować jako historyka, czy jako teologa Kościoła? Podejrzewam, że nie da się zweryfikować empirycznie czegoś takiego jak ciągłość doktrynalna Kościoła. Pytanie trzecie: czy Focjusz rzeczywiście fałszował dokumenty, czy jest to tylko insynuacja Skargi? - Bo przecież odmienny przekład czy interpretacja same w sobie mogą być uznane za fałszowanie.

Do drugiego referatu. Generalnie jest tak, że Piotr Skarga traktował Kościoły wschodnie inaczej niż protestantów. Skarga wychodził z założenia, że stanowiska doktrynalne Kościoła prawosławnego są zbieżne z doktryną katolicką i wystarczy, aby „grecy” uznali prymat papieża.

Dr Tomasz Stolarczyk (Uniwersytet Łódzki):

Na początku XIII wieku na południu Francji pojawił się gigantyczny problem katarów. Niejaki Dominik Guzman postanowił założyć zakon, który przeszedł do historii jako Zakon Braci Kaznodziejów. Celem dominikanów było głoszenie Słowa Bożego na wzór apostołów, aby zwalczać herezję. Władcy francuscy organizowali krucjaty na „heretyków” z południa, a św. Dominik uważał, że trzeba nawracać Słowem Bożym, a nie ogniem i mieczem. Do tego konieczne było gruntowne wykształcenie i dobrze zorganizowane struktury zakonu, czego przykładem stali się właśnie dominikanie. Później nastąpiły ogromne wstrząsy religijne, jak schizma zachodnia, podczas której część zakonu opowiedziała się za papieżem rzymskim, inna część za awiniońskim. Następnie przyszedł wiek XVI i reformacja. Ówczesny zanik klasztorów dominikańskich odzwierciedla stan całego Kościoła katolickiego. Wówczas także niejaki eks-żołnierz Ignacy Loyola powołał do życia zakon jezuitów. Zakon ten miał za zadanie powstrzymanie reformacji i, aby to uczynić, musiał być tak nowoczesny, jak zakon dominikanów trzy wieki wcześniej. Uważam zatem, że trzeba by zgłębić całą myśl jezuicką, kiedy rozpatruje się działalność Skargi. I jest to uwaga zarówno do Pana Dawida Szymczaka, jak i do Pani Krystyny Krawiec-Złotkowskiej — położyć większy nacisk na środowisko jezuickie. Odnajdziemy tu odpowiedź na pytanie, dlaczego stanowisko jezuity wobec prawosławia było takie a nie inne. W średniowieczu uważano, że schizmatyk jest gorszy od poganina. Tak samo w XVI wieku.

\section{Dr Anna Kapuścińska:}

Z dużą radością przyjmuję powrót tematyki wschodniej. Skarga jako historyk — to bardzo umowna forma traktowania autora; prędzej powinien być traktowany jako teolog historii duchowości. Nie wiem, czy rozważał Pan, na ile praca Melchiora Cano miała wpływ na postrzeganie historii - auctoritas historiae humanae. Czyli że Skarga mógł wykorzystywać historię jako argument teologiczny. W tym znaczeniu jest to procedura metodologiczna teologa, a nie historyka w ścisłym znaczeniu. Czy widzi Pan możliwość rozpatrywania Rocznych dziejów kościelnych w kontekście ustaleń Cano i jego szkoły?

Teraz do Pani Krystyny Krawiec-Złotkowskiej. Postuluję, aby nie porównywać św. Katarzyny i kazań renesansowych. Tekst scholastyczny i tekst o proweniencji patrystyczno-renesansowej to dwa różne porządki i mamy tu metodologiczny zgrzyt. Mam też pytanie, w oparciu o jakie źródła wnioskuje Pani, że innowiercy naśladowali Skargę? Porządek dowodzenia i argumentacji zaaprobowany przez sobór trydencki jest zupełnie inny niż porządek dowodzenia luteran. I jeszcze odnośnie kwestii światła, może należałoby wydobyć te wszystkie elementy, które leżą w materii teologicznej? Bo to, że Skarga powołuje się na Pismo Święte i Ojców Kościoła, jest rzeczą całkowicie naturalną. Pani podkreśliła słusznie, że św. Marcin jest patronem światła. I to leży w obrębie inventio. Może o tym dałoby się nieco więcej powiedzieć?

\section{Dr Michał Kuran:}

Pozwolę sobie zadać kilka pytań Panu Radosławowi Rusnakowi. Po co przekładano tekst, o którym Pan mówił? Czy są jakieś różnice merytoryczne (sens, bieg akcji) między wersją oryginalną i polskim 
tłumaczeniem? Czy w przekładzie są wprowadzane elementy kultury rodzimej, świadczące o próbie polonizacji tego utworu? Czy na podstawie cech języka da się ustalić, z jakiego regionu pochodził autor?

Panią Doktor Krawiec-Złotkowską zapytam o dwie sprawy: czy Skarga w tym kazaniu w jakikolwiek sposób odnosi się do osoby Marcina Lutra? Co z retorycznością wypowiedzi kaznodziei? Czy do analizy tych środków nie byłyby przydatne narzędzia retoryczne?

Mam jeszcze pytania do Pani Doktor Rusińskiej-Giertych. Czy istnieje szczegółowa bibliografia druków lwowskich? Którą z tamtejszych tłoczni należy uznać za ośrodek bardziej znaczący? Czy dałoby się porównać produkcję wydawniczą tych ośrodków? Wspomniała Pani o zmianach zachodzących w liczbie publikowanych tekstów literackich. Na tej podstawie można stwierdzić, że dość późno jezuiccy drukarze lwowscy zainteresowali się literaturą. Czy teksty, jakie drukowali, weszły do praktyki szkolnej? Bo tak było na przykład z wydaną w Kaliszu przez tamtejszą drukarnię kolegium jezuickiego Wojną domowa Samuela Twardowskiego, która później znalazła się w zespole utworów wykorzystywanych w nauczaniu szkolnym.

\section{Dr Radosław Rusnak:}

Jeżeli chodzi o ewentualny cel stworzenia translacji, tekstu z różnych względów odmiennego od tego, czym mogli interesować się bazylianie, sądzę, że decydująca jest siła ekspresji, sposób ujęcia tematu. Nie ma podobnych tekstów o tej tematyce, a specyficzna wojna siepaczy Heroda z Młodziankami ma w sobie olbrzymi potencjał wyobrażeniowy, estetyczny i przede wszystkim religijny. Możemy tu mówić o splataniu się owej religijności z tematyką militarną, z niezdrową fascynacją śmiercią, grozą, turpizmem. Jeżeli chodzi o zgodność tekstu, o którym mówimy, z oryginałem, to jest ona duża. Spośród ponad czterystu oktaw wypada ich tylko pięć, z czego trzy stanowiące dedykację Antoniowi d' Alba, wicekrólowi Neapolu. Kontekst przynależności utworu do konkretnej epoki czy miejsca jest całkowicie pomijany, podobnie jak nawiązania do Arpina. W każdym razie wierność jest priorytetem autora, choć nie odmawia on sobie prawa do spolszczeń — choćby w tytulaturze wojskowej. Natomiast o kwestii regionu, z którego pochodził autor, pisał Brückner. Według badacza, jest to rejon północnych Kresów Wschodnich. Pominąłem zagadnienia dialektologiczne.

\section{Dr Michał Kuran:}

Chodzi o to, że analiza dialektalnych cech językowych może ułatwić identyfikację autora. I jeszcze pytanie o cel: chodziło o docere czy delectare?

\section{Dr Radosław Rusnak:}

Wciąż jeszcze są kierunki, jakie można by podjąć. Na przykład pytanie, w jakim stopniu bazylianie znali język włoski? Czy utrzymywali kontakty kulturowe z Italią? W kwestii celu powiedziałbym, że bardziej movere i dopiero poprzez nie osiągnięcie celu dydaktycznego.

\section{Mgr Dawid Szymczak (Uniwersytet Łódzki):}

Nasunęło mi się pytanie, właściwie nie tyle do Pana Doktora Rusnaka, co do Profesora Radyszewskiego, który, niestety, nie dojechał do nas; pytanie dotyczące charakteru i liczby tłumaczeń, czy w ogóle literatury obcej, przedostającej się do środowiska bazyliańskiego (ile tego było?) a następnie zestawienie tego ze środowiskiem kijowsko-mohylańskim. Celem takiego porównania, zakładając, że coś z tego wyniknie, byłoby uchwycenie wpływów kultury zachodniej na poszczególne regiony Wschodu, którego przebudzenie zaobserwować można od XVI-XVII wieku.

\section{Dr Radosław Rusnak:}

Interesowałoby mnie to, jak wyglądała sytuacja przyswajania sobie kultury zachodniej w środowisku prawosławnych bazylianów. Jeśli chodzi o unickich bazylianów, o których mówiłem, to oni są jednym z bardziej prężnych ośrodków, który, na równi z jezuitami, adaptował i krzewił tę kulturę. Interesowały ich nie tylko teksty religijne, dlatego wybór Marina nie jest zaskakujący.

\section{Mgr Dawid Szymczak:}

Wracając do pytań odnoszących się do mojego wystąpienia, chciałbym w pierwszej kolejności podziękować za cenne uwagi. 
Najpierw pytanie Pana Doktora Kwoska. Skąd wiadomo, kto się od kogo odłączał? Nie rozstrzygniemy tego na poziomie dyskusji historycznoliterackiej. W praktyce było tak, że obydwie strony wysuwały przeciwko sobie te same lub bardzo podobne argumenty. Problem zatem leżał w tym, aby nie dopuścić do sytuacji, w której argumentacja byłaby pozbawionym weryfikowalności źródłowej, dowodowej, czy erystycznej zbijaniem racji przeciwnika na zasadzie „to wy jako pierwsi się odłączyliście”. Z naszego punktu widzenia — jako literaturoznawców czy językoznawców — nie jest to, a przynajmniej nie w pierwszej kolejności, problem teologiczny, ale właśnie retoryczny.

Czy bardziej należałoby traktować Skargę jako historyka, czy jako teologa? Nie stawiałem sobie za cel rozstrzygania tej, skądinąd prowokacyjnej, kwestii, która chyba już na pierwszy rzut oka wydaje się oczywista - i nie dlatego, że tak wynika z sądów utrwalonych w tradycji badawczej, lecz po prostu dlatego, że w czasach, kiedy Skarga działał, nie istniało jeszcze pojęcie historii jako samodzielnej nauki. Była to dziedzina pomocnicza dla retoryki i teologii. Chciałbym nadto zwrócić uwagę na fakt, że patrzenie na Skargę wyłącznie przez pryzmat jego kaznodziejskiej działalności, jak miało to miejsce dawniej, nierzadko prowadziło na manowce, bo kosztem takiej kwalifikacji pomijano, a niekiedy wręcz nie dostrzegano aspektów twórczości, których głębsze zbadanie mogłoby dostarczyć naprawdę interesujących ustaleń. I jednym z takich aspektów jest właśnie zagadnienie historii — jej treści, sposobów ujęcia oraz celów, jakie przypisywał jej Skarga.

\section{Dr Anna Kapuścińska:}

Ad vocem. Owszem, Skarga był kaznodzieją, ale to zaledwie jeden z licznych nurtów jego działalności. W związku z tym posługiwanie się wyłącznie tą kategorią byłoby zawężające. Natomiast rozstrzygnięcie problemu „teolog czy historyk” jest istotne tylko pod względem metodologicznym. Skarga był teologiem, a w obrębie teologii mamy historię Kościoła, teologię duchowości, hagiografię, epistolografię chrześcijańską, teologię ascetyczno-mistyczną i mnóstwo innych rzeczy, które mieszczą się w tym szerokim nurcie.

\section{Dr Jacek Kwosek:}

Chodziłoby zatem o ustalenie tego, w jaki sposób Skarga używał historii. Bo historia jest po prostu rezerwuarem zdarzeń, które można różnie interpretować.

\section{Mgr Dawid Szymczak:}

Sprawa jezuitów, którą poruszył Pan Doktor Stolarczyk. Nie ulega wątpliwości, że osadzenie Skargi w środowisku, z którego wyszedł, jest niezwykle istotne, a wręcz nieodzowne. Ratio studiorum czy słynna Bibliotheca selecta Possevina — dwie fundamentalne pozycje — determinowały właśnie od strony środowiskowej charakter twórczości i nie sposób tego nie uwzględniać. Należy wszakże unikać niebezpieczeństwa popadania w drugą skrajność, polegającego na porzuceniu próby poszukiwania autonomiczności czy samodzielności w tym piśmiennictwie - i nie chodzi tu bynajmniej o kwestie dogmatyczne, lecz o indywidualność twórczą.

Przy okazji wyszła sprawa zależności Skargi od innych twórców. Roczne dzieje były, jak wiadomo, kompilacją monumentalnego dzieła kardynała Baroniusza, ale patrzenie wyłącznie pod tym kątem również mogłoby zaprowadzić w ślepą uliczkę. Per analogiam, ostatnie dziesięć lat pokazało, że to, co dotychczas robiono z Żywotami świętych, określając je nierzadko jako dzieło wtórne w pewnym sensie, właściwie nie miało podstaw. Dopiero próby ukazania głębi myślowej po jednej stronie, a samodzielnie ukształtowanego warsztatu po drugiej pozwoliły stwierdzić, że Skarga nie był wtórny i wcale nie brakowało mu oryginalności, a jego teksty nie były kompilacjami w znaczeniu negatywnym.

\section{Dr Anna Kapuścińska:}

Stąd właśnie moje pytanie. Czy to nie ustalenia Melchiora Cano popchnęły go do tego, żeby zająć się historią? Bo oto mamy z historii argument teologiczny i w obrębie tej procedury możemy robić to, co w ramach swej oryginalności, inwencyjności, wiedzy, jesteśmy w stanie wyargumentować. Jestem zwolenniczką tezy, którą Pan głosi, a mianowicie, że to dzieło w pierwszej kolejności oryginalne i niezależne, a dopiero w następnej zainspirowane pewnymi bodźcami literackimi i teologicznymi. 


\section{Dr Tomasz Stolarczyk:}

Chodziło mi o to, aby rozpatrywać Skargę jako jezuitę, ale także jako człowieka Kościoła. Oczywiście, był także indywidualnym umysłem, więc jakieś pierwiastki od siebie wnosił. Wspomnę jeszcze o estymie, jaką cieszyli się jezuici jako polemiści. W dominikańskich bibliotekach klasztornych najwięcej po dominikańskich autorach było jezuitów. Krótko mówiąc, jezuici byli wówczas wielką potęgą umysłową świata zachodniego.

\section{Mgr Dawid Szymczak:}

Jeszcze mam jedną uwagę do Pani Doktor Krawiec-Złotkowskiej. Skarga rozróżniał pojęcia schizmatyka, heretyka i poganina. To były trzy odmienne typy, nazwijmy to, osobowości. Wszystkie miały wydźwięk negatywny, przy czym w najlepszej sytuacji był poganin. Nie znał on Boga, a w pewnych momentach historii był nawet biczem Bożym, narzędziem karania schizmatyków i heretyków za grzechy. Schizmatycy natomiast znali Boga, lecz wyrzekli się prawdziwej wiary, w tym wypadku przez odrzucenie papieskiej supremacji.

\section{Dr Krystyna Krawiec-Złotkowska:}

Pozwolę sobie odpowiedzieć w kolejności zadawanych pytań. Najpierw jednak dziękuję Panu Doktorowi oraz Panu Magistrowi za zwrócenie uwagi na rozbieżność pogańską, heretycką i schizmatycką. Powołam się na źródło bezpośrednie i będzie to także częściowa odpowiedź Panu Doktorowi Kuranowi. Początkowo Skarga nie wymienia Lutra z imienia i jest to fragment, który się odnosi do innowierców w ogóle. Autor pisze: „Ariańska nauka przez tysiąc lat pod ławą piekielną gniła: dopiero ją uczniowie kalwińscy wyrwali. Ebiońska świeca przed 14 set lat pod korcem szatańskim leżała: dopiero ją Nowochrzczeńcy ukazują. Obrazoborska przed 800 lat w gnoju leżała: dopiero ją Hugonoci wykopali. Sakramentalska przed 600 lat zakopana była: dopiero ją Kalwin i Zwingiel wzniecił" ${ }^{4}$. On tu wymienia różne odłamy heretyckie. Nie wchodziłam szczegółowo w ten problem, bo nie było to przedmiotem kazania. Luter, przywołany z imienia, pojawia się w dalszym akapicie, w którym Skarga, krytykując nauki innowiercze stwierdza, że „z innego ognia świece swoje zapalili: od Lutra, od Kalwina, od Zwingla. Ich ogień z piekielnej zazdrości i nienawiści ku duchowieństwu wyszedł. Z piekielnej się pychy i nadętości rozumu [...] wykrzosał, w którym żadnej pokory i cichości, i zgody apostolskiej i chrześcijańskiej nikt nie poczuje; z którego się nikt do pobożności i żywota dobrego i doskonałego nie zapali. Ale raczej do cielesności, rozpustności, swejwolej, każdy się z niego podnieci”s.

Pan Doktor Kwosek zasygnalizował problem ciągłości tradycji. Jeśli dobrze zrozumiałam, sugeruje Pan, że nie można mówić o tej ciągłości.

\section{Dr Jacek Kwosek:}

Mówić można, tylko nie ma dowodów czysto empirycznych.

\section{Dr Krystyna Krawiec-Złotkowska:}

Ale słowne, leksykalne i kulturowe są. Skoro istnieją pewne toposy i archetypy, które funkcjonują nie tylko w tradycji literackiej, ale także w mentalności, rozumieniu, wartościowaniu pewnych przestrzeni, które nas otaczają, to jak najbardziej możemy mówić, że wyrastamy z jakiejś tradycji, jesteśmy jej dziedzicami i kontynuatorami. Łączy się to też z naszą indywidualną wrażliwością, która ma wpływ na wartościowanie poszczególnych zjawisk. W każdym razie możemy mówić o pewnych zjawiskach ciągłych, które się rozwijają i które być może są modyfikowane w procesie historycznoliterackim czy kulturowym.

Zwracam się do Pana Doktora Stolarczyka. Myślę, że w przypadku analizy jednego wybranego kazania szczegółowe wniknięcie w kwestie jezuickie byłoby zbędne. Pojawiłoby się wtedy zbyt wiele wątków i dygresji, które mogłyby zburzyć kompozycję wypowiedzi, a ja starałam się przedstawić tytułowy problem w sposób logiczny. Do Ignacego Loyoli odwołałam się tylko w kontekście etymologii jego imienia, która, nawiasem mówiąc, też nie jest jednoznaczna. Świadomie nie wchodziłam w struktury, filozofię, ideologię zakonu jezuitów.

\footnotetext{
${ }^{4}$ P. Skarga, Kazanie na dzień ś. Marcina biskupa, [w:] tenże, Kazania na niedziele i święta catego roku, t. 6, Lipsk 1843, s. 155.

${ }^{5}$ Tamże, s. 156.
} 
Jeśli chodzi o pytanie Pani Doktor Kapuścińskiej o to, skąd wzięła się św. Katarzyna w moim przykładzie, odpowiadam: stąd mianowicie, że sam Skarga przywołuje ją w omawianym utworze. Porównuje św. Marcina do św. Katarzyny i św. Cecylii. Autor twierdzi, że św. Marcin należy do tej samej grupy sług Bożych, co św. Katarzyna, to znaczy tych, którzy „stali na świeczniku Bożym i świecili”.

\section{Dr Anna Kapuścińska:}

Tu się zgadzam. Katarzyna jest świętą brewiarzową. Ale Kazanie na dzień św. Katarzyny to jest relikt polski, rękopiśmienny i leżący w zdefektowanej postaci w klasztorze. Skarga nie znał tego kazania i nie ryzykowałabym odwołań do tekstu, tylko do kultu św. Katarzyny, który w Kościele katolickim był mocny.

\section{Dr Krystyna Krawiec-Złotkowska:}

Chodziło mi o wykazanie podobnej kompozycji i budowy kazań. Obydwa utwory mają układ klamrowy, a w przypadku kazania Skargi jest to podwójny układ klamrowy. Najpierw pojawia się postać św. Marcina, która przywołana jest na zakończenie części pierwszej, a potem jeszcze raz w passusie hagiograficznym na zakończenie. I jeszcze jedna klamra — św. Marcin jest na początku i na samym końcu. Na początku i na końcu pojawia się także wywód o świetle. Światło kończy kazanie. Pomijałam w tym kontekście konstrukcje retoryczne, inwencję. Także to, że u Skargi elementy docere są wzbogacane przez delectare.

\section{Dr Anna Kapuścińska:}

Jest to niezbędne, bo nie może być ani samo docere, ani samo delectare.

\section{Dr Krystyna Krawiec-Złotkowska:}

Dokładnie. Chodzi o to, że mamy do czynienia z konstrukcją spójną, wyrastającą z tradycji retorycznej. Co z tej retoryki wynika? To, że argumenty są w większym stopniu asymilowane przez potencjalnego odbiorcę, gdyż nie są pozbawione warstwy oddziałującej na naszą percepcję świata. W kilku momentach Skarga straszy tych, którzy ufają zmysłom i „za obcym ogniem pójdą”. Wprowadza przy tym elementy eschatologiczne.

Skąd wniosek, że innowiercy naśladowali Skargę? Nie potrafię odpowiedzieć na to pytanie w tej chwili, ale pisze o tym Zbigniew Zielonka i ja powołuję się na jego ustalenia ${ }^{6}$. Natomiast to, że styl Skargi był akceptowalny nie tylko w środowiskach katolickich, ale także w protestanckich, nie odnosi się bezpośrednio do kwestii konfesyjnych, tylko do leksykalnych.

\section{Dr Anna Kapuścińska:}

Nie był to więc styl Skargowski, tylko po prostu dobra szkoła humanistyczna, cycerońska łacina przetransponowana na możliwości języka polskiego. Podobnie do Skargi pisze choćby Jakub Górski — te same struktury zdaniowe.

\section{Dr Krystyna Krawiec-Złotkowska:}

Skarga cieszył się dużym autorytetem i dlatego pozwoliłam sobie stwierdzić, że miał swoich naśladowców. Recepcja romantyczna jest najlepszym przykładem na to, jak Skargę oceniano w procesie historycznoliterackim. Miałam zresztą na myśli nie tylko recepcję Skargi w późniejszych epokach, ale również opinię Jadwigi Sokołowskiej, która pisze o tym, że niektóre kazania Skargi mają taką samą rangę w Polsce, jak Bousseta we Francji. Sokołowska stwierdza, że te kazania należą do arcydzieł obu literatur?

Dr Halina Rusińska-Giertych (Uniwersytet Wrocławski):

Zacznę od pytania dotyczącego bibliografii. Istnieją takie opracowania, przede wszystkim bibliografia druków lwowskich Rudolfa Kotuli ${ }^{8}$. Autor wymienia tam sporo tekstów tłoczonych w drukarni jezuic-

\footnotetext{
${ }^{6}$ Z. Zielonka, Piotr Skarga. „Żywoty świętych”. „Kazania Sejmowe”, [w:] Historia literatury polskiej w dziesięciu tomach, t. 2, Renesans, red. A. Skoczek, Bochnia [2006], s. 344-345.

${ }^{7}$ J. Sokołowska, Dwie nieskończoności. Szkice o literaturze barokowej Europy, Warszawa 1978, s. 111.

${ }^{8}$ R. Kotula, Bibliografia polskich druków lwowskich XVI-XVIII w., Lwów 1928.
} 
kiej. Poza tym, oczywiście, Bibliografia polska Karola Estreichera. Jest jeszcze opracowanie ukraińskich badaczy Jarosława Isajewycza i Jakyma Zapaski'. Jest to katalog starodruków wydanych na Ukrainie.

Jeśli chodzi o porównanie drukarni lwowskiej i kaliskiej, to obie były tłoczniami prowincjonalnymi, jednak ta druga rozwijała się zdecydowanie prężniej. Wynikało to z faktu, iż oficyna kaliska dysponowała przywilejami i monopolem na tłoczenie określonych grup piśmiennictwa (m.in. w latach 1710 i 1726 konstytucji sejmowych, od 1744 podręczników na użytek szkół w Prusach i Wielkopolsce, od 1746 „Alwara”, od 1769 słownika Grzegorza Knapskiego). Drukarnia lwowska była skromnym ośrodkiem lokalnym, powstała głównie dla potrzeb kolegium i tak naprawdę rozrosła się dopiero w latach czterdziestych siedemnastego wieku. Wówczas to zaczęła odbijać podręczniki dla wszystkich szkół jezuickich w Małopolsce i Rusi Czerwonej. I choć jej rozkwit, trwający do zamknięcia zakładu w roku 1773, był imponujący, to w opinii historyka jezuickiego — Stanisława Bednarskiego, wyrażonej w Drukarzach dawnej Polski ${ }^{10}$, wśród tłoczni jezuickich lwowska ustępowała miejsca Wilnu, Poznaniowi i Kaliszowi.

Trzecie pytanie odnosiło się do publikacji drukowanych na potrzeby szkolne. Owszem, drukowano takie teksty. Była im podporządkowana także literatura piękna. Z drugiej strony te druki publikowano również z myślą o polskim środowisku intelektualnym, które niejednokrotnie sponsorowało wydawanie tekstów. Ambicją kolegium lwowskiego było koncentrowanie wokół siebie intelektualistów polskich. Analogicznie w przypadku drukarni stauropigialnej, gdzie drukowano książki cyrylickie, koncentrowano środowisko ruskie.

\section{REFERATY WYGŁOSZONE W SESJI POŁUDNIOWEJ}

dr Michał Kuran, Hagiograficzny wizerunek świątobliwej wdowy Doroty Barzi — konstruowanie wzorców osobowych w kazaniu o. Adama Makowskiego „Roczna i wieczna pamiątka”

dr Anna Reglińska-Jemioł, Reminiscencje sztuki tanecznej w piśmiennictwie jezuickim

dr Ireneusz Szczukowski, Ciało skazańca. Wokót Przewodnika mitosiernego (Trakt VII) Marcina Józefa Nowakowskiego

\section{Dr Jacek Kwosek:}

Ja bym powiedział jedną rzecz odnośnie ostatniego referatu. Tutaj można by nawiązać do słów z Ewangelii, że tylko Duch daje życie, ciało na nic się nie przyda. Jeżeli my dzisiaj w coraz większym stopniu podejmujemy problematykę naszej korporalności, to musimy pamiętać, że wyłącznie ciało uduchowione jest nośnikiem sensu. Ciało nie zawierające w sobie żadnej intencjonalności samo nic nie mówi.

Dr Ireneusz Szczukowski (Uniwersytet Kazimierza Wielkiego):

Jedyną sygnaturą ciała była antropologia chrześcijańska. Można jeszcze dodać, że ciało było rozumiane przez pryzmat lektury Księgi Rodzaju. W Raju, jak tłumaczyli Ojcowie Kościoła, człowiek nie był nagi, lecz przyodziany szatą łaski. Można powiedzieć, że w dawnej kulturze jedynym liczącym się ciałem było ciało cierpiącego Chrystusa.

\section{Dr Krystyna Krawiec-Złotkowska:}

W wystąpieniu Pana Doktora Szczukowskiego ciało zostało pokazane w sposób deprecjonujący, jako coś, co pozbawia człowieka duchowości. Natomiast czy w tym kazaniu jest jakakolwiek aluzja do sceny na Golgocie, gdzie Chrystus powiedział do skazańca: „Twoja wiara cię uzdrowiła i dziś jeszcze będziesz ze mną w Raju"?

\section{Dr Radosław Rusnak:}

W pierwszej kolejności mam pytanie do Doktora Szczukowskiego. Jak rozumie Pan sformułowane przez Pana nawiązanie do Bachtinowskiego dołu materialno-cielesnego? Ja zrozumiałem, że jest to prze-

\footnotetext{
${ }^{9} \mathrm{~J}$. Isajewycz, J. Zapasko, Pam’jatki knyżkovoho mystectva. Kataloh starodrukiv vydanych na Ukraini. Knyha persza (1574-1700), L'viv 1981; Knyha druha, czastyna persza (1701-1764), L'viv 1984; Knyha druha, czastyna druha (1765-1800), L'viv 1984.

${ }^{10}$ Drukarze dawnej Polski od XV do XVIII wieku, z. 6: Małopolska - Ziemie Ruskie, oprac. A. KaweckaGryczowa, K. Korotajowa, W. Krajewski, Wrocław 1960, s. 114.
} 
strzeń, w której umiera to, co stare i grzeszne w tym skazańcu i jest szansa, że przez poniesione upokorzenie i cierpienie dojdzie do odrodzenia się nowego człowieka. Natomiast nie ma tu całego kontekstu kultury karnawałowej.

Drugie pytanie odnosi się do Pani Doktor Reglińskiej-Jemioł. Zrozumiałem, że obecność tańca w teatrze jezuickim jest konsekwencją rozpowszechnienia się trendów tanecznych w całej ówczesnej kulturze. Czy samo wprowadzenie scen tanecznych ma związek z poszukiwaniem nowożytnej formuły teatru w nawiązaniu do teatru antycznego - tak jak miało to miejsce w operze? Opera ma być tym bliższa modelowi antycznemu, że większy nacisk kładzie się na śpiew. A wiemy, że chór grecki nie tylko udzielał się wokalnie, ale też tanecznie. Czy istnieją jakieś teoretyczne teksty mówiące o genezie tego zjawiska?

\section{Dr Ireneusz Szczukowski:}

Do Doktora Kurana. Czy w omawianym kazaniu pojawiają się odwołania do tekstu św. Hieronima Adversus Jovinianum, gdzie pojawia się spór o wyższość dziewictwa nad małżeństwem? Czy to kazanie nie jest pokłosiem sporów między katolikami i protestantami także o wyższość dziewictwa i wdowieństwa nad małżeństwem? Czy dotarł Pan do kazań dotyczących Zofii Tylickiej, Gostomskiej i Ostrogskiej?

\section{Dr Anna Kapuścińska:}

Do Pana Doktora Kurana. Czy jest możliwe, że możemy mówić o pokłosiu Skargowskiego rozumienia świętości i propagowaniu jej dla każdego? Hagiograficzne wzory Skargi zaraz po jego śmierci weszły w sferę obiegu popularnego, ale może w elitarnym środowisku jezuickim ta idea, przynajmniej w produkcji kaznodziejskiej, przetrwała.

Natomiast do Pana Doktora Szczukowskiego mam pytanie, czy możliwe, że oprócz wizerunku Chrystusa miały tu wpływ wizerunki innych męczenników?

\section{Dr Anna Reglińska-Jemioł:}

W odpowiedzi na pytanie dotyczące teoretycznych traktatów, w których poruszana była sprawa teatru antycznego, mogę się odwołać do dzieła Menestriera, które skrótowo Państwu przedstawiłam, tej pierwszej encyklopedii tańca. Autor dokonuje przeglądu sztuki tanecznej od czasów najdawniejszych, powołując się na teoretyków, w tym na Lukiana z Samosat, który napisał traktat o tańcu. Dostrzega zatem wagę rozwoju myśli tanecznej od czasów najdawniejszych. Wydaje mi się jednak, że fenomen tańca w tym okresie na scenach jezuickich łączy się z kulturą dworską, etykietą, modą i pewnym rodzajem edukacji. W tym czasie pojawił się Ludwik XIV i rozwój tańca kojarzyć należy z jego osobą. Moda przenoszona przez jezuitów przedostawała się także do naszego kraju, choć w mniejszym stopniu niż to było na Zachodzie. Taniec na scenach szkolnych opierał się na krokach tańca, który dziś nazwalibyśmy towarzyskim, czyli mogliśmy oglądać tam na przykład kroki menueta czy gawota.

\section{Dr Michał Kuran:}

Odpowiem najpierw na pytanie Pana Doktora Szczukowskiego. W kazaniu nie pojawiły się żadne odwołania do św. Hieronima. Nie ma też nawiązań do sporu katolików i protestantów o wyższość dziewictwa nad małżeństwem. Autor zakłada milcząco, że bohaterka wyszła za mąż i nie rozwija dalej wątku. Chwali zalety wdowieństwa, ale w żadnym wypadku nie deprecjonuje małżeństwa. Nie poszukiwałem też kazań poświęconych innym heroinom kontrreformacji. W omawianym przeze mnie utworze występuje jednak matka Anny Alojzji Ostrogskiej, co pokazuje pewną tradycję życia w stanie wdowim w tej rodzinie.

Co do pytania Pani Doktor Kapuścińskiej, myślę że jak najbardziej tak — jest to pokłosie Skargowskiego rozumienia świętości. Zwróciłbym jeszcze uwagę na pewne wykorzystanie kazania rocznicowego (równie dobrze mogło to być kazanie pogrzebowe) z włączeniem do niego tendencji hagiografizującej, a poza tym wprowadzenie współczesnych, a nie jak w Żywotach świętych, odległych bohaterów. Autora interesowała biohagiografia i musiała to być kontynuacja działalności Skargi.

\section{Dr Ireneusz Szczukowski:}

Jeżeli chodzi o odwołanie do sceny z Ewangelii według św. Łukasza, to u Nowakowskiego nie znalazłem nawiązań. 
Jeśli chodzi o Bachtina, użyte sformułowanie o dole materialno-cielesnym było obecne w moim tekście jako pewna klisza czy metafora pozostająca w oderwaniu od Bachtina.

Natomiast co do wypowiedzi Pani Doktor Kapuścińskiej, przyznam Pani rację. Kod Prudencjusza, szerzej opisów męczeństwa w pismach apologetów i Ojców Kościoła byłby istotny, przy czym skazaniec byłby naznaczony dawką cierpienia, tak samo jak męczennik, ale byłby nośnikiem negatywności ciała i grzechu — w przeciwieństwie do świętości męczennika.

\section{Dr hab. prof. UŁ Krystyna Płachcińska:}

Mam jedną ogólną uwagę. Zauważcie Państwo, jak bardzo naszą różnorodną tematykę zdominowała cielesność w krańcowym wydaniu. Zastanawia mnie, jak to jest, że w piśmiennictwie zakonnym cierpienie i erotyzacja sacrum, wręcz fascynacja nimi, występuje aż w takim natężeniu? Inna rzecz, że aby wyrazić miłość, jakkolwiek byśmy ją rozumieli, mamy w języku do dyspozycji tylko topikę erotyczną.

\section{Dr Jacek Kwosek:}

Można by pokusić się o łatwe psychologizowanie — jak się jest zakonnikiem, to ciało bardziej doskwiera, udręcza, i nie chodzi tu bynajmniej tylko o sferę seksualności.

\section{Dr Anna Kapuścińska:}

W przypadku pisarzy starochrześcijańskich to chyba wcale nie było łatwe psychologizowanie, lecz intuicja. Tam, gdzie trzeba się wyrzec ciała, pojawia się pożądanie w krańcowym wydaniu. W żywocie św. Hilariona pojawia się passus o dwóch męczennikach, z których pierwszy wysmarowany jest miodem i gryzą go muchy, a drugi jest przywiązany miękkimi girlandami do łoża i kuszony przez nierządnice. Ten drugi właśnie odgryza sobie język i pluje nim kobietom w twarz, by zahamować ból pożądania. Wydaje się, że wszędzie w myśli chrześcijańskiej, gdzie pojawia się odrzucenie cielesności, w podtekście będzie erotyka. Można też powołać się na współczesne badania nad poezją zakonną. Badaczki zajmujące się poezją zakonnic dowodziły, że miłość do Chrystusa, jakkolwiek bardzo czysta i nieskalana, przekazywana jest przez pryzmat języka cielesności i kod erotyczny.

\section{Dr Jacek Kwosek:}

Jeśli chodzi o sytuację poddawania ciała umartwianiu, to nawet nie są intuicje, ale po prostu fakty. Człowiekowi przychodzą do głowy takie myśli, o które by siebie nie podejrzewał. Co więcej, jest to w pewnym sensie sytuacja komfortowa, bo o wiele łatwiej jest zlokalizować własne żądze jako wroga niż własną pychę. Jeśli chodzi natomiast o łączenie cierpienia i miłości, to jest taki wiersz George’a Herberta, w którym pojawia się metafora sadu, którego się przycina:

Niechaj mnie, zlęknionego, Boża dłoń OTOCZY

Niech raczej nóż Twój ostry soki ze mnie TOCZY

Niżbym miał poczuć, Panie, żeś odwrócił OCZY ${ }^{11}$.

\section{Dr Michał Kuran:}

Chodzi zatem o ascetyczne doświadczenie ciała poprzez umartwienie w celu kształtowania heroizmu duszy.

\section{Dr Krystyna Krawiec-Złotkowska:}

W Emblematach Zbigniewa Morsztyna, o których wczoraj wspominałam, wciąż pojawiają się żądze. Oblubienica wielokrotnie powtarza: „O, niechaj krzyżuję żądze, które w sobie czuję”. A zatem ona chce swoje pragnienia i cielesność ukrzyżować jako sferę grzeszną, ale z drugiej strony tylko za pomocą takiego języka może wyrazić swe dylematy.

\footnotetext{
${ }^{11}$ G. Herbert, Raj, przeł. St. Barańczak, „Ogród” 1991, nr 3, s. 45. Wiersz pochodzi ze zbioru The Temple. Sacred poems and private ejaculations, ed. N. Ferrar, Cambridge 1633.
} 


\title{
REFERATY WYGŁOSZONE W SESJI POPOŁUDNIOWEJ
}

\author{
dr Jacek Kwosek, Inspiracje filozoficzne w „De acuto et arguto” Macieja Kazimierza Sarbiewskiego \\ mgr Piotr Dąbrowski, Idee wychowania moralnego i obywatelskiego w "Rozmowach konwiktorów” ks. Anto- \\ niego Wiśniewskiego SchP \\ dr Dorota Szagun, Cztery cnoty zakonne w XVI-wiecznej regule zakonu św. Klary
}

\section{Dr Krystyna Krawiec-Złotkowska:}

Mam jedną refleksję w związku z wystąpieniem Pana Doktora Kwoska. Chodzi konkretnie o cytowanego węża. Jak rozumiem, w pierwszym znaczeniu występował on jako desygnat, $w$ drugim — jako pojęcie, które określa ten desygnat. Trzeci aspekt to sfera mentalna — to, jak my sobie wyobrażamy węża. A co ze sferą metaforyczną?

Mam jeszcze pytanie do Pani Doktor Szagun. Spotkałam się z interpretacją etymologiczną słowa ubóstwo, że pochodzi ono od wyrażenia przyimkowego „u Boga”. Nie ma to nic wspólnego z biedą. Tak właśnie można tłumaczyć biblijny zwrot „błogosławieni ubodzy duchem”. Czy reguła Urbana IV z 1263 roku, którą Pani przywoływała, nie odnosi się do sfery duchowej, a nie materialnej? Wydawało mi się, że „ubodzy duchem” to ci, którzy się nie wynoszą, pokorni. Chodzi tu o grzech pychy.

\section{Dr Jacek Kwosek:}

Drugie znaczenie węża odnosiło się do samego wyrazu — tego, jaki on jest. Nazwa ma dwie strony. Jedna to zawartość treściowa, a druga to „fizyczność” tej nazwy. Supozycja materialna to fizyczna strona nazwy. Dodam tylko, że Sarbiewski nic nie pisze w De acuto et arguto na temat supozycji prostych i podobnych rzeczy. Supozycje odnoszą się tylko i wyłącznie do tego, w jaki sposób używa się danych terminów dosłownie. W przypadku metafory dochodzą jeszcze dodatkowe mechanizmy.

Mam jeszcze pewną uwagę odnośnie do zwrotu „błogosławieni ubodzy”. To pojawia się w Ewangelii św. Mateusza, natomiast u św. Łukasza pojawia się tylko „ubodzy”. I ta druga wersja jest wersją pierwotną. Wersja św. Mateusza jest pewnego rodzaju dodatkiem. Cały dowcip polegał jednak na tym, aby właściwie oddać sens hebrajskiego słowa anawim. Anawim to ludzie, którzy nic nie mogą, nie liczą się. Ci właśnie są błogosławieni. Dlatego Mateusz pisze „ubodzy duchem”, to znaczy tacy, którzy nie chcą znaczyć, nie chcą być możni. Drugi sposób oddania sensu słowa anawim to „błogosławieni, którzy cierpią prześladowania dla sprawiedliwości”.

\section{Dr Anna Kapuścińska:}

A jak to brzmiało w bulli papieskiej? Pewnie jako dosłowne tłumaczenie ubóstwa materialnego. Czy to będzie od miserum, czy od pauperum, to na jedno by wyszło. Na przełomie XV i XVI wieku znaczenia tych wyrazów były utożsamiane. Niestety, wtedy łacina patrystyczna odeszła już w zapomnienie, stąd podobne zjawiska. Jak kto znał łacinę, tak sobie ją tłumaczył.

\section{Dr Jacek Kwosek:}

Mam jeszcze jedną refleksję do referatu Pana Dąbrowskiego. Mówił Pan, że oni zwalczali deistów. A zatem uznajemy, że deistami byli Macchiavelli i Rousseau (co do tego drugiego sam nie jestem pewien), a zatem ludzie, którzy niekoniecznie mieli ochotę rozstrzygać to, czy Pan Bóg ingeruje w dzieje świata, czy jest tym Bogiem odległym, który tworzy świat, a następnie abdykuje. Stąd ogólna refleksja, że być może pojęcie „deizm” odnosi się nie tyle do konkretnego stanowiska filozoficznego czy teologicznego, lecz do pewnego nurtu myślowego, który staje w jakiejś opozycji do chrześcijaństwa. Tu mieściłby się Macchiavelli, który twierdził, że chrześcijaństwo, jako doktryna polityczna, zawiodło.

Dr Dorota Szagun (Uniwersytet Zielonogórski):

Zacznę od etymologii wyrazu „ubogi”. Wiele terminów ze sfery religijnej, w tym Bóg, nie wywodzi się tylko z zapożyczeń, ale ma charakter prasłowiański, czyli są to tak zwane neosemantyzmy. Jeśli zatem chodzi o wyraz „ubogi”, to pierwszym znaczeniem nie jest „Bóg”, tylko „bogactwo”. Kierunek etymologiczny jest więc zupełnie odwrotny w stosunku do tego, jaki sugerowali Państwo — nie „ubogi” od „Boga”, tylko „Bóg” od „ubogiego”. „Ubogi” to ktoś, kto nie posiada majętności, sławy, „niebogaty”. 
Stąd dopiero „Bóg”, który jest dawcą siły, majętności, bogactwa i tak dalej — wyraz ten to neosemantyzm. W epoce przedchrześcijańskiej wyraz „bóg” oczywiście istniał, lecz nie miał kontekstu religijnego, podobnie jak „piekło”. Prasłowianie oddawali cześć swoim bóstwom z imienia. Nie było jednej istoty najwyższej, więc i leksem na jej określenie nie był potrzebny. Neosemantyzacja dotyczyła wielu wyrazów, które weszły do języka wraz z chrześcijaństwem. Chociaż już na płaszczyźnie staropolszczyzny można by się zastanawiać, czy słowo „ubogi” rzeczywiście nie funkcjonowało w dwóch znaczeniach: „u Boga” i „niemajętny”?

Czy reguła, o której mówiłam, odnosi się do sfery duchowej, czy materialnej? Starałam się wykazać, że choć pierwiastki duchowe były obecne, to sama reguła nie odnosi się do sfery duchowej. Reguła nie porządkuje tego, w co siostry miały wierzyć — od tego jest Biblia, pisma Ojców Kościoła i tak dalej. Reguła natomiast porządkuje fizycznie życie wspólnoty. Jest zatem mowa o tym, jak mają wyglądać drzwi, jak mają być zamykane, które ściany mają być murowane.

Co do sprawy oryginału, zakłada się, że istniał tekst łaciński. Natomiast sam tekst odpisu sporządzony był przez kilku skryptorów. Reguła musiała być czytana, a zatem istnieje hipoteza, że jej tekst ulegał zaczytywaniu i pojawiała się konieczność ponownego spisywania. Stąd nie można na tę chwilę ustalić, czy jest to odpis oryginału, czy może którejś z wcześniejszych wersji polskich. Abstrahując od tekstu reguły, cała rzeczywistość, w jakiej reguła powstawała, mówi o tym, że wszystkie inne akty konstytutywne dla wspólnoty klarysek zmierzały do tego, aby osobny przywilej ubóstwa, w znaczeniu nieposiadania majątku klasztornego, wyrugować z całego zbioru reguł. Reguła wprowadza poniekąd dwa osobne terminy — czym innym jest ubóstwo, a czym innym brak własności. Pod tym względem wydaje się uprawnione mówienie, że o ile brak własności jest przez tę regułę podtrzymywany, o tyle brak majątku już nie. Stan majątków klasztorów klarysek w Polsce był dość pokaźny.

\section{REFERATY WYGLOSZONE W SESJI WIECZORNEJ}

dr Małgorzata Mieszek, „Od miękkich niewieścich afektów daleki umyst”, czyli Jan Bielski wobec Stanistawa Konarskiego

Joanna Woron, Reminiscencje antyczne i staropolskie w „Opisaniu Kalinowskich” ks. Hermana Drobiszewskiego

mgr Agata Wdowik, Debiuty literackie pokolenia Ignacego Krasickiego

\section{Dr Radosław Rusnak:}

Referat Pani Agaty Wdowik był jednym z niewielu, który oddaje spektrum wiedzy ogólnej. Mam uwagę do ostatnich kilku akapitów, stanowiących podsumowanie Pani referatu. Wydawało mi się, że pokolenie traktuje Pani jako umowną kategorię, mającą dać pewne orientacyjne wnioski co do „przejścia kulturowego”. Zastanawiałem się, w jakim znaczeniu używa Pani słowa pokolenie. Wydaje mi się, że chodzi tu o szeroki zakres pojęcia, czyli przy uwzględnieniu wszystkich możliwych odmienności, jakie dzielą ludzi urodzonych mniej więcej w tym samym czasie. W związku z tym mam kolejne pytanie, czy uważa Pani, że to pojęcie jest w ogóle nośne dla chronologizacji i periodyzacji literatury dawnej?

Mam też pewne uwagi do wystąpienia Pani Joanny Woron. Michałowska ustaliła ${ }^{12}$, że błędnie uznaje się Szołuchę za autora Historyj dziwnych i niezwyczajnych. Od lat sześćdziesiątych ubiegłego wieku przyjmuje się, że autorem ich jest Tomasz Stefan Nargielewicz. Poza tym wspomina Pani o koniu trojańskim. On pojawia się w Eneidzie, a nie w Iliadzie. Ponadto skonstatowała Pani zdecydowanie analogię między polonizacją, czyli przesycaniem adaptacji obcych wzorów w romansach elementami polskimi, i europeizacją, czyli inkrustowaniem tekstu oryginalnego nawiązaniami do literatury obcej. Ja nie widzę tu analogii. Wpisywanie kontekstu kanonicznych tekstów jest powszechnym elementem praktyki literackiej. I ostatnia rzecz. Tonacja adaptacji Trenu $X$ ma charakter poważny, tak? Czy jednak wobec odmiennej formy gatunkowej, w jakiej ten tekst się pojawia, nie można by uznać go za parodię, wziąwszy pod uwagę, że romanse stały o wiele niżej w hierarchii gatunkowej? Czy, Pani zdaniem, nie jest to naruszenie decorum?

\footnotetext{
${ }^{12}$ T. Michałowska, „Różne historyje”. Studium z dziejów nowelistyki staropolskiej, Wrocław 1965.
} 


\section{Dr Krystyna Krawiec-Złotkowska:}

Ad vocem. Zdaję sobie sprawę z tego, że Pani Joanna Woron oparła się na utrwalonej w tradycji literackiej (profesorowie Pelc i Grzeszczuk) interpretacji tego tekstu — że jest to tren lamentacyjny, gdzie dochodzi do całkowitego załamania się światopoglądu itp. Ta interpretacja budzi mój wewnętrzny sprzeciw. Nie odczytuję Trenu $X \mathrm{w}$ kategoriach lamentu i rozpaczy ani też w kategoriach załamania światopoglądowego. Uważam, że ten utwór ma od początku do końca charakter erudycyjny. Powiem prowokacyjnie, że Kochanowski popisuje się tam własną wiedzą na temat możliwości egzystencji duszy po śmierci człowieka. Słowa „gdzieśkolwiek jest, jeśliś jest” nie muszą być wcale traktowane jako świadectwo zwątpienia w życie pozagrobowe. „Jeśliś jest” odnoszę do epikureizmu. Epikurejczycy mówili, że dusza jest śmiertelna, tak jak ciało, stąd chociażby słynne carpe diem. Jest to zatem potencjalna możliwość, że dusza nie ma bytu pośmiertnego. Pisałam o tym już piętnaście lat temu ${ }^{13}$, ale zasięg czytelniczy był bardzo lokalny. Niedługo zamierzam do tematu wrócić i poszerzyć spektrum analizy w oparciu o inne utwory Jana Kochanowskiego; w związku z tym również chcę rozwinąć problematykę Trenu XIX, w którym pojawia się matka. Słowa, które wypowiada: „Ludzkie przygody ludzkie noš”, odczytywane przez Pelca i Grzeszczuka jako pogłębiony humanizm chrześcijański, są, według mnie, powrotem Kochanowskiego do źródeł. Matka ujawnia się jako archetyp, pierwszy nauczyciel — jeszcze przed filozofami. Wracając do Trenu $X$, nie wyobrażam sobie, żeby Kochanowski mógł zapomnieć o epikureizmie, będącym przecież przez dwadzieścia lat niemalże jego religią. $Z$ nauczycielem można się nie zgadzać, ale w żadnym razie nie można go zlekceważyć. Powracając już do Pani wystąpienia, uważam, że powinna Pani zaznaczyć, na czyją interpretację Trenu $X$ powołuje się.

\section{Mgr Joanna Woron:}

Odnośnie parodii, o której wspomniał Pan Doktor. Wcześniej nie odczytywałam tego tekstu pod tym kątem, ale jest taka możliwość. Odczytam Państwu parafrazę Trenu X. Uważam, że przyda się w dyskusji.
Oto Lament Ochmistrzyni z Opisania Kalinowskich:
Panno moja, gdzie mi się podziała,
Czyliś żywo porwana z śmiertelnego ciała?
Czyliś gdzie z Prozerpiną w ostatnie odnogi
Wezbrała Tyzyfona? Czyliś uwieziona
Precz od nieślachetnego za Wisłę Jazona
I za miałki Dziurdzistan? Który mi opowie
Demofoon o twojej nieświadomej głowie?
Czy Pegazów lotnemi uniesiona pióry,
Tańce wodzisz na górze Helikonie z córy
Jowisza? Czy tyrana wozem podziemnego
Zawieziona do gaju stąd Elizejskiego?
Czyli Cię orle skrzydli z tak wieży wysokich
$\mathrm{Na}$ Apenin wyniosły, że wirów głębokich
Wisły zmierzyć nie mogłaś? Czy Gerydon który,
Dziś znowu odrodzony, wykradł z takiej góry -
Nie wiem. Czy, gdzie Wulkan na szczudle, za Tulen głęboki
I Islandy dalekie, zaniosły wyroki,
Które padły na ciebie, Boga Wszechmocnego? ${ }^{14}$

\section{Dr Jacek Kwosek:}

Czasami nawiązanie zależy od tego, jak my daną rzecz interpretujemy. A tu jest takie nawiązanie, że pasowałoby niezależnie od sposobu odczytania Trenu X.

${ }^{13} \mathrm{~K}$. Złotkowska, Gdzieśkolwiek jest..., [w:] Stupskie szkice polonistyczne. Zbigniewowi Zielonce z okazji Jubileuszu czterdziestu lat stużby literaturze i nauce — przyjaciele, koledzy, wspótpracownicy, Słupsk 1996, s. $173-179$.

${ }^{14}$ H. Drobiszewski, Opisanie Kalinowskich, „Ze skarbca kultury” 1960, z. 1, s. 215. 
Mgr Agata Wdowik (Uniwersytet Warszawski):

Przyznaję, że sama miałam obiekcje, jeśli chodzi o kategorię pokolenia. Początkowo zajmowałam się kategorią pokolenia biologicznego i badałam zależności pomiędzy określonymi elementami biografii przedstawicieli danego pokolenia (pochodzenie stanowe, podróże, poglądy polityczne). Ograniczony zasób danych z wieku osiemnastego, ale też brak możliwości ich weryfikacji sprawiły jednak, że zaczęłam nabierać coraz większych wątpliwości co do użyteczności kategorii pokolenia biologicznego.

Natomiast w badaniach nad procesem historycznoliterackim istotniejsza wydaje mi się kategoria pokolenia kulturowego, którego jedną z części składowych jest pokolenie literackie. Z kolei zakres tego pojęcia jest, to prawda, również niejasny. Słusznie też zauważył dr Radosław Rusnak, że posługuję się pojęciem pokolenia w jego szerokim znaczeniu, które — poza uwypuklaniem miejsc wspólnych — uwzględnia wszelkie możliwe odmienności, jakie są udziałem osób urodzonych mniej więcej w tym samym czasie. W badaniach nad piśmiennictwem dawnym kategoria pokolenia literackiego, pomimo swojej ogólności i niedoprecyzowania, wydaje mi się pożyteczna zarówno ze względu na wszystkie te pokoleniowe doświadczenia, które łączą, jak i te, które dzielą ludzi o zbieżnej dacie urodzenia, a które z różnym natężeniem, ale wpływają na współtworzone przez nich życie literackie, w tym, rzecz jasna, twórczość.

Innymi słowy, nie obstawałabym mocno przy stwierdzeniu, że pojęcie pokolenia literackiego można z sukcesem funkcjonalizować w celu ściślejszego uchwycenia periodyzacji literatury dawnej. Odnoszę jednak wrażenie, że kategoria pokolenia (biologicznego, kulturowego, literackiego), ze wszystkimi swoimi wewnętrznymi odstępstwami, ma jednak charakter porządkujący i sprzyja opowiadaniu o życiu literackim czasów dawnych.

\section{Dr Jacek Kwosek:}

Słowo znaczy to, co każemy mu znaczyć, a zatem wystarczy, że sobie Pani zdefiniuje pokolenie literackie tak, jak będzie się Pani podobało i zaznaczy tylko w przypisie, że zdaje sobie sprawę z niejednoznaczności pojęcia.

Mam jeszcze jedno pytanie do referatu Pani Doktor Mieszek. Czy Bielskiemu chodziło o to, żeby nie było nawet postaci kobiecych?

Dr Małgorzata Mieszek (Uniwersytet Łódzki):

Tak, to wynikało z ostatecznej wersji Ratio studiorum. W regule dla rektora wyraźnie zaznaczono, że nie należy na scenę „,wprowadzać ani ról, ani kostiumów kobiecych”. Inna sprawa, że w praktyce reguły dotyczące teatru były wielokrotnie przekraczane. Pisał o tym m.in. ks. Jan Poplatek w swoich Studia chz dziejów jezuickiego teatru szkolnego w Polsce ${ }^{15}$.

\section{Dr Jacek Kwosek:}

O ile dobrze pamiętam, to również Platon był przeciwnikiem odgrywania przez mężczyzn ról kobiecych, co jakoby sprzyjało rozwojowi ducha niemęskiego, który następnie przenosił się na życie. Zastanawia mnie jednak pewna niespójność. Z jednej strony to, co mówi Bielski, odnosi się tylko do teatrów konwiktowych, a z drugiej strony uważa, że tam, gdzie są role kobiece, rodzą się miękkie afekty i zamiast efektu katarktycznego mamy jego przeciwieństwo. Z tego wynikałoby, że tragedie, w których są postacie kobiece, nie wywołują efektu katarktycznego. Bielski zatem jakby mówi, że można wprowadzać role kobiece, ale i tak nie będzie to prawdziwa tragedia.

\section{Dr Małgorzata Mieszek:}

Bielski, niestety, nie unika pewnych nielogiczności i to zarzucali mu badacze. Warto dopowiedzieć, że należał on do pokolenia "awangardzistów” — tych, którzy uzyskali już nową edukację i byli otwarci na nowe wzorce, niemniej jednak nadal pozostawali zobligowani w stosunku do reguł zakonnych. To samo stanowisko powtórzył zresztą Bohomolec - u nas nie wolno, ale u innych proszę bardzo. Krótko mówiąc, ma się wrażenie, że Bielski broni tezy, która wobec następujących wokół zmian, jest czysto teoretyczna.

\footnotetext{
${ }^{15}$ J. Poplatek SJ, Studia z dziejów jezuickiego teatru szkolnego w Polsce, Wrocław 1957, passim.
} 


\section{Dr Anna Reglińska-Jemioł:}

Kreacje kobiece były obecne w baletach. Było to, rzecz jasna, przyczyną krytyki ze strony jezuitów. Uczniowie malowali się, wkładali suknie i peruki w celu odegrania ról żeńskich, na przykład Wiosny. Mówiło się, że są osobne reguły dla całego zakonu, osobne dla Francuzów i osobne dla paryżan.

\section{Dr Jacek Kwosek:}

Chcę dodać, że w którymś z esejów Jana Kotta na temat Szekspira pojawia się spostrzeżenie, że dramatopisarz wykorzystywał to, że role kobiece odgrywali często młodzi aktorzy.

\section{Sobota, 6 listopada 2010 roku}

\section{REFERATY WYGLOSZONE W SESJI PRZEDPOŁUDNIOWEJ}

dr Rafał Kępa, Inkunabuly kanonickiej proweniencji w zbiorach Biblioteki Uniwersytetu Wroctawskiego dr Magdalena Kuran, $Z$ problematyki kaznodziejstwa oo. reformatów

mgr Karolina Agata Podleśna, Wzorzec mariologii jasnogórskiej w spóźnionym „sarmatyzmie” na przykładzie panegiryku koronacyjnego "Splendor korony z dwunastu gwiazd... "(1717 r.)

mgr Ewa Maciejczyk, Symbolika światta w obrazie Maryi w wybranych pieśniach kręgu bernardyńskiego dr Katarzyna Kiszkowiak, Topika Mater Dolorosa w „Rozmyślaniach dominikańskich”

\section{Dr Jacek Kwosek:}

Do ostatniego wystąpienia. Pani Doktor Kiszkowiak mówiła, że te rozmyślania są z ducha średniowieczne, ponieważ autor puścił wodze fantazji, zrobił apokryf. Jest to opinia Górskiego i ja się z nią nie zgadzam. W czasach kontrreformacji pilnowano, aby różnego rodzaju nie sprawdzone historie nie były przekazywane, ale z drugiej strony, po okresie soboru trydenckiego, koncentrowano się na podkreślaniu roli Maryi. aby w ten sposób zaznaczyć sprzeciw wobec protestantyzmu. Tekst rozpatrywany przez Panią doskonale się w to wpisuje. Co więcej, generalnie nie pisano wówczas apokryfów o Matce Boskiej, ale za to teologowie - jeszcze XIX- i XX-wieczni — popuszczali wodze fantazji. Jeden z teologów informował na przykład, jak Maryja wyglądała. To wszystko podaję na odpowiedzialność Beinerta, który napisał o powyższych sprawach książkę ${ }^{16}$. Słuchając Pani tekstu, również miałem odczucie, że brzmi on średniowiecznie, ale myślę, że uzasadnienie, które Pani podaje za Górskim, nie będzie odpowiednie. Rzecz kolejna - mówi Pani, że skoro dominikanie kładli nacisk na intelektualne pogłębienie, a autor, mówiąc kolokwialnie, poszedł po bandzie i nie był dokładny, to w takim razie nie jest to tekst dominikański. Czy w XVI wieku jeszcze pilnowano poziomu dominikanów? Autor mógł być wykształcony, ale nawiązał do konwencji — a że nie był dokładny, to nic szczególnego. Poza tym, były różne stopnie dokładności. Dlaczego w ogóle uznaje się ten tekst za należący do duchowości dominikańskiej? Z uwagi na podkreślanie kultu Jezusa i Maryi. A może spojrzeć na to inaczej? To znaczy nie rozstrzygać, czy autor rzeczywiście był dominikaninem, czy nie, bo być może nie dysponujemy danymi na ten temat. W związku z tym możemy poprzestać na kwestii, czy tekst został sporządzony w kręgu duchowości dominikańskiej, czy nie.

Jeszcze uwaga do drugiego wystąpienia. Pani Doktor Kuran mówiła, że uczono się na Cyceronie, ale niekoniecznie stosowano się do jego zaleceń. Przypomina mi się spór azjanistów z attycystami. Zastanawiam się, na jakiej zasadzie opierano się na tym Cyceronie...

\section{Dr Radosław Rusnak:}

Odwołując się do przedmówcy, mnie również nie przekonuje argument odnośnie do domniemanej „niedominikańskości” autora. Przyczepiłbym się jeszcze do rozłożenia akcentów w przypadku Pani wypowiedzi. Topika Mater Dolorosa nakazywała spodziewać się położenia większego nacisku na sposób przeżywania samej Męki Pańskiej. Scena pożegnania Jezusa i wymiany spojrzeń, gdy odchodzi On w stronę Ogrodu Oliwnego, jeszcze nie jest samym spektaklem Pasji. W tym przypadku sama topika jeszcze się nie realizuje. Natomiast ja bym położył nacisk na wzmianki, które Pani podała, sumując wypowiedź. Być

16 W. Beinert, Drogi i bezdroża mariologii, przeł. J. Zychowicz, Warszawa 1993. 
może, ciekawe byłoby też postawienie pytania, jak się ma udział Matki Bożej wobec tego odkrycia reinkarnalności Chrystusa. Inna kwestia, która mogłaby wzbogacić wystąpienie, to jak się ma ujęcie cierpień Matki Bożej do innych przedstawień. Ja mam wrażenie, że są one niezwykle zbieżne.

I odnośnie wystąpienia Pana Doktora Kępy, mam tylko glosy. Nazwał Pan Józefa Flawiusza autorem pogańskim — z tym nie można się zgodzić. I druga rzecz — w reasumowaniu geograficznym tych druków ja bym zastąpił nazwy dzisiejsze nazwami historycznymi.

\section{Dr Tomasz Stolarczyk:}

Dwie sprawy. Najpierw kwestia poziomu intelektualnego dominikanów w XVI wieku. Początkowo ten zakon był bardzo uczony. Aby głosić Słowo Boże, trzeba było naprawdę sprawnych teologów. Z biegiem czasu zakon ten zaczął pomału podupadać - szczególnie w XVI wieku, kiedy reformacja przetrzebiła zakony i to chyba wszystkie, w tym dominikanów. Jeśli chodzi o prowincję polską, to, zwłaszcza na Śląsku, klasztory znikały w tempie błyskawicznym, nawet z dnia na dzień. Jeśli chodzi o tereny Rzeczypospolitej Obojga Narodów, wyglądało to nieco lepiej, ale niewiele. W pewnym momencie sytuacja zaczęła się bardzo pogarszać, coraz mniej było w nich nowicjuszy. Na przykład w Łęczycy — jeśli w latach siedemdziesiątych XV wieku było trzynastu zakonników, to na początku XVI wieku, tych zakonników było zaledwie sześciu. Zaczęto więc przyjmować do zakonu ludzi, mówiąc brzydko, z łapanki, w dodatku właściwie nie wiadomo, czy umiejących czytać i pisać. Było tam, oczywiście, studium podstawowe łaciny, ale poziom intelektualny był coraz słabszy. W wizytacjach prowadzonych przez władze zakonu podkreśla się, że prowincja polska jest, mówiąc krótko, upośledzona dosyć mocno. Oczywiście, w niektórych klasztorach podejmowano próby reform, ale szło to z bardzo dużymi oporami. Dopiero w wieku XVII sytuacja zaczęła zmieniać się na lepsze.

Mam jeszcze uwagę do Doktora Kępy. Wydaje mi się, że we wszystkich zgromadzeniach istniał żelazny kanon lektur, który każda biblioteka musiała zawierać - wybrani Ojcowie Kościoła, potem Bellarmin, Skarga, Wujek i tak dalej. Mogły występować różnice w proporcjach — jednego autora było mniej, innego więcej, jeszcze innego nie było, ale generalnie pozycje powtarzają się. Mam w związku z tym pytanie: czy w zbiorach kanoników regularnych musiały być jakieś naprawdę żelazne pozycje, które były istotne głównie dla kanoników? W przypadku dominikanów byli to na przykład św. Tomasz i Piotr Lombard.

\section{Dr hab. prof. UŁ Krystyna Płachcińska:}

Nawiążę do wypowiedzi skierowanej do Pani Doktor Kiszkowiak. To był początek XVI wieku, więc niekoniecznie mogliśmy obserwować efekty, o których Pan mówi. Następnie, czy to nie jest tak, że popyt wytwarza pewną podaż? Że jest zapotrzebowanie na ten typ wykładów — prosty, odwołujący się do wyobraźni, który nawet bardzo wykształcony dominikanin tworzy i dostosowuje do moźliwości i potrzeb odbiorców?

\section{Dr Anna Kapuścińska:}

Pani Profesor wyraziła moje myśli i podejrzenia. Już pod koniec XV wieku praktyka w wielu zgromadzeniach była taka, że doraźna potrzeba duszpasterska kształtowała określony typ dyskursu. Tekst danego autora, pisany na potrzeby wewnętrzne zakonu, nie miał nic wspólnego z jego produkcją zewnętrzną, która czasem schodziła do poziomu audytorium — i bardzo słusznie, bo audytorium miało z tego jakieś korzyści.

Po drugie, przestrzegałabym przed stosowaniem kryterium chrystocentryczności i mariocentryczności jako kryterium konstytutywnego. Jakie bowiem miały być te zakony? Chrystocentryczne i mariocentryczne. Jest to zatem kryterium dość śliskie.

\section{Dr Jacek Kwosek:}

Nie wspominając już o tym, że franciszkanie forsowali doktrynę o Niepokalanym Poczęciu, natomiast dominikanie szli za św. Tomaszem z Akwinu.

\section{Dr Magdalena Kuran:}

Do uwagi o Cyceronie. Dla mnie też jest intrygujące, że oni się uczyli na tym samym zestawie autorów, na tym samym podręczniku. Kiedy porównuję, co z tego wynieśli Wujek i Skarga, a co autorzy siedemnastowieczni, stwierdzam, że efekt jest zupełnie inny, choć wynika to zapewne po części z innego 
charakteru epoki, z innego rozłożenia akcentów. Widać to szczególnie w zachowanych rękopisach z zakresu retoryki.

\section{Dr Jacek Kwosek:}

Cyceron nie był attycystą. U niego są wątki azjańskie, które on dopuszcza.

\section{Dr Magdalena Kuran:}

Dyskusji o stylu jest sporo wśród tekstów, które analizowałam, natomiast żaden z tych tekstów nie wyróżnia takiego podziału.

Mam jeszcze jedną uwagę w sprawie soboru trydenckiego. Intencjonalnie miał on być momentem przełomowym - choćby w kwestiach zerwania z tradycją apokryficzną; zabroniono używania sekwencji w liturgii. Mimo wszystko, niekoniecznie przeniosło się to na praktykę. Analizowałam kazania wielkopiątkowe z XVII wieku i liczba zastosowanych tam treści apokryficznych jest przeogromna. A zatem sobór trydencki wcale nie był takim jednoznacznym przecięciem pewnych zwyczajów.

Dr Rafał Kępa (Uniwersytet Łódzki):

Mam wątpliwości, czy tych starszych autorów, nie cechujących się szeroko pojętą starożytnością, istotnie można nazwać Ojcami. Zdaje się, że taką opinię o Skardze tu usłyszałem.

Natomiast jeśli chodzi o pytanie, które zadał Doktor Stolarczyk, trudno odpowiedzieć. Na pewno duchowość kanoników regularnych, których właściwie trudno nazwać zakonem - to forma wspólnotowego życia księży kanoników — oparta ona była na regule św. Augustyna i być może wyrażało się to w liczbie zachowanych egzemplarzy. Pytanie, czy św. Augustyn był tak istotny tylko dla kanoników regularnych? Jako Ojciec Kościoła na pewno mieścił się w kanonie pism obowiązkowych dla wielu zgromadzeń. Podobnie zresztą jak św. Tomasz.

Co do uwag Pana Doktora Rusnaka, nie pozostaje mi nic innego, jak przyznać Panu rację — zarówno w sprawie Józefa Flawiusza, którego zbyt pośpiesznie i ogólnie potraktowałem jako poganina, a w domyśle chodziło mi o autora niechrześcijańskiego, jak i nazewnictwa historycznego w miejsce współczesnego - geograficznego.

Dr Katarzyna Kiszkowiak (Uniwersytet Gdański):

Bardzo serdecznie dziękuję Państwu za wszystkie uwagi. Rozpoczynę od odpowiedzi Panu Doktorowi Kwoskowi. Jak zaznaczyłam, przytaczałam opinię Górskiego, ale uwzględnię kontekst, który Pan Doktor proponuje, bo podkreślanie roli Maryi w celu przeciwstawiania się protestantyzmowi, jest rzeczywiście bardzo istotne.

Jeśli natomiast chodzi o uwagę większości z Państwa o tę „dominikańskość” autora i tekstu, jesteśmy w bardzo trudnej sytuacji. Ciężko bowiem ustalić poziom intelektualny dominikanów w XVI wieku, nie możemy też powiedzieć, jak wykształcony był sam anonimowy autor. Natomiast sugestia, że autor mógł pisać swoje teksty na potrzeby konkretnego odbiorcy, niezależnie od dzieł, które mogły powstawać w zakonie dla potrzeb wewnętrznych, jest rzeczywiście cenna. Zgodzę się też z sugestią Pana Doktora Kwoska, aby dokonać zawieszenia sądów i nie pytać o autorstwo, lecz o usytuowanie tekstu w ramachpewnej duchowości.

W związku z wypowiedzią Pana Doktora Rusnaka, odnośnie topiki Mater Dolorosa powiem tylko, że w swoim wystąpieniu chciałam skupić się na wycinku utworu. Doskonale zdaję sobie sprawę, że cała Pasja składa się z różnych etapów i autor Rozmyślań dominikańskich te etapy uwzględnia. Pomiędzy początkowym i końcowym punktem węzłowym dzieła — scenami pożegnania w Betanii i scenami Ukrzyżowania — w kolejnych epizodach Męki widzimy Maryję na drugim planie, ale jest Ona stale obecna, co chwilę Jej postać powraca. Zgadzam się, że topika Mater Dolorosa miałaby największą wyrazistość w scenach końcowych, tylko moim zamiarem było skupienie się na scenach początkowych.

\section{Dr Magdalena Kuran:}

Chciałabym zasugerować, żeby bardziej ostrożnie używać pojęcia „gatunek”, bo jednak panegiryk jest formą ponadgatunkową. Do pani Maciejczyk — kiedy pod koniec mówiła Pani o bernardynach i ich roli w rozwoju kultu pasyjnego, to jest to spojrzenie ahistoryczne, bo Pani mówi o XV wieku i osadza 
tam stacje drogi krzyżowej, natomiast pojęcie stacji i drogi krzyżowej powstaje dopiero pod koniec XVII wieku i na początku XVIII, a w dodatku ustalili to nie bernardyni, lecz franciszkanie reformaci. Pojawia się też jeszcze przy Hozjuszu zbyt ogólnikowe stwierdzenie o dopuszczeniu tylko katolickich i starych — chodziło chyba o pieśni. Owszem, to jest związane z Trydentem, ale trzeba dookreślić, o co chodzi, zwłaszcza z tymi „starymi”.

Chciałam podzielić się jeszcze jedną refleksją. Tutaj pojawił się apokaliptyczny obraz Maryi, obleczonej w Słońce, mającej Księżyc pod stopami i wieniec z gwiazd. Większość odbiorców jest przyzwyczajona do odczytywania tej postaci właśnie jako Maryi, natomiast ja spotkałam się w kazaniach Stefana Ponińskiego, jezuity z początku XVIII wieku, ze szczegółową analizą tego obrazu, gdzie autor dostrzegał w nim postać Marii Magdaleny — nawiasem mówiąc trochę nielogicznie, bo kiedy pojawił się wątek poczęcia dziecka, które zmiażdżyło głowę węża, to nie bardzo było wiadomo, co z tym zrobić. A zatem jeszcze w osiemnastym stuleciu hermeneutyka chrześcijańska nie utożsamiała postaci z apokaliptycznego obrazu wyłącznie z Maryją.

\section{Dr Anna Kapuścińska:}

Do wystąpienia pani Maciejczyk. Nie można używać terminu „topos Wniebowzięcia”. To może być temat, ale na pewno nie topos. Może być topika solarna czy lunarna, ale nie topika Wniebowzięcia. Pani mówi o pewnych fabularnych zapleczach liryki maryjnej, ale kiedy Pani analizuje swoje teksty, nie mówmy o fabule utworu. Pani stwierdziła ponadto, że dopiero średniowiecze zaczęło eksplorować wątki maryjne, które nie były obecne w Biblii. Jednak akomodację wątków mariologicznych obserwujemy już w późnym antyku. W przypadku średniowiecza nie mamy natomiast jeszcze dokładnie zbadanych kanałów dystrybucji i innowacji tych wątków; być może częściowo zostały przetransponowane przez Hilarego z Poitiers. Natomiast średniowiecze na pewno znało, przynajmniej cząstkowo, odpryski wschodniej liryki maryjnej.

\section{Dr hab. prof. UŁ Krystyna Płachcińska:}

Nie możemy mówić wprost, a tak to zabrzmiało, o obrazie Maryi w Pieśni nad Pieśniami.

\section{Dr Michał Kuran:}

Uwaga do pani Karoliny. Jak rozumiem, tekst, który Pani omawia, został napisany na jakąś oficjalną okazję. A zatem nie mógł go pisać młody adept.

Mgr Karolina Agata Podleśna (Uniwersytet Kardynała Stefana Wyszyńskiego):

Powiem tylko, że paulini jakby narzucają przypisywanie tego tekstu Juniewiczowi. W taki sposób figuruje to w bibliografii zakonu paulinów, ale ja tutaj nie mam pewności.

\section{Dr Michał Kuran:}

A co się da ustalić archiwalnie?

\section{Mgr Karolina Agata Podleśna:}

Niewiele. Ciężko jest dotrzeć do archiwum Jasnej Góry. Natomiast wszyscy za Estreicherem podają, że autorem jest Dionizy Jan Chełstowski.

\section{Dr Michał Kuran:}

A opis uroczystości?

\section{Mgr Karolina Agata Podleśna:}

Mówi nam o kilku autorach.

\section{Dr Michał Kuran:}

Ale mi chodzi o to, czy istnieje jakaś inna relacja z tej uroczystości?

\section{Mgr Karolina Agata Podleśna:}

Owszem, jest, ale nie ma tam mowy o tym kto jest autorem tego konkretnego tekstu. Prawdopodobnie podczas uroczystości były wygłoszone różne utwory panegiryczne. 


\section{Dr Anna Kapuścińska:}

Jak rozumiem, chodzi o konwent, gdzie byli nowicjusze. A czy mamy informację, kto był mistrzem nowicjatu? Bo być może właśnie to on był autorem tekstu. Warto sprawdzić nazwiska opiekunów nowicjatu.

\section{Mgr Karolina Agata Podleśna:}

Wspomniałam, że konwent był fundatorem wydania i niekoniecznie musiał pochodzić stamtąd autor. Juniewicz był wówczas w nowicjacie, ale samo to nie jest dowodem autorstwa. Jednak późniejsze prace tego autora, zwłaszcza panegiryki, sugerują, że wykazywał się talentem już w początkach życia zakonnego, co zostało zauważone i wykorzystane przy okazji wrześniowej uroczystości koronacji obrazu Matki Bożej.

\section{Dr Michał Kuran:}

To mogła być zbiorówka, chociaż ktoś tego pilnował. Sam podział na części to sugeruje. Można by także przyjrzeć się całości od strony stylistycznej.

\section{Dr Anna Kapuścińska:}

To by się nawet zgadzało. Zdarzało się, że w podobnych przypadkach kimś takim, to znaczy opiekunem literackim, był mistrz nowicjatu, i później było to wydawane.

Mgr Ewa Maciejczyk (Uniwersytet Łódzki):

Chciałam podziękować za wszystkie głosy. Zgodzę się z tym, że w przypadku Wniebowzięcia mamy do czynienia z tematem, a nie toposem.

Jeśli chodzi o Hozjusza, to on miał na myśli teksty paraliturgiczne. Zastanawiałam się, czy nie było to związane z laudes dramaticae, które wywodziły się z tradycji włoskiej i zawierały elementy pieśni o Słońcu, a ponadto należały do widowisk paraliturgicznych.

\section{Dr Anna Kapuścińska:}

Hozjusz zajął się bardziej wdrażaniem reformy trydenckiej, a włoskie źródła były mniej ważne.

\section{ZAMKNIĘCIE OBRAD}

\section{Dr hab. prof. UŁ Krystyna Płachcińska:}

Parę słów na zakończenie. Pierwsza refleksja: ogromna różnorodność materiału. Pewnie stanie się ona przyczyną rwania włosów z głowy dla redaktora monograficznego tomu, który będzie próbował ten materiał jakoś poukładać. Natomiast dla nas oznacza ona bogactwo inspiracji, i to jest wielki plus. Nie oczekiwałam, że będzie to aż taka różnorodność pod względem tematów, czasów i środowisk, w których się zanurzamy.

Druga refleksja: odniosłam wrażenie, być może mylne, ogromnej, miażdżącej wręcz przewagi problematyki dotyczącej działalności jezuitów. Nie chcę dociekać przyczyny tego; czy po prostu chętniej do nich sięgamy, czy może chodzi o lepszą dostępność źródeł, lepszy marketing? W każdym razie widać znaczną przewagę wystąpień im poświęconych w stosunku do innych zgromadzeń zakonnych.

Kolejna refleksja jest taka, że było to piśmiennictwo - paradoksalnie — bardzo bliskie życia. Ciągle dostrzec je można było tuż obok zainteresowań zakonnych. Zaryzykowałabym stwierdzenie, że nasza literatura zakonna była miernikiem tętna życia swojego czasu. Myślę sobie o pierwotnie planowanym tytule konferencji: „Za klasztorną furtą”. A gdzież tu furta?! Jakie „za”, jeśli ta furta jest szeroko otwarta? Tę szczególną bliskość obserwujemy zarówno w średniowieczu, jak i w baroku. Dotyczy to także bliskości w aspekcie metafor, toposów, stylistyki. Czasem jest ona tylko wskaźnikiem pulsu życia, a czasem ów puls pobudza, wyprzedza go w pewien sposób. To daje do myślenia.

Przede wszystkim jednak pragnę Państwu serdecznie podziękować za przyjazd i za to, że dzięki temu spotkaniu mamy napęd do dalszej pracy. Do tego, żeby znowu iść w nasze środowiska, gdzie nas szczególnie nie cenią i najchętniej by nas do rezerwatów pozamykali, dając jeść tylko tyle, by nie zamorzyć nas głodem. Tu natomiast widzimy, że my, staropolanie, jesteśmy liczni i silni; że czerpiemy z siebie nawzajem różne inspiracje; że jesteśmy zgromadzeniem, choć może nie zakonnym. Także raz jeszcze dziękuję za udział w konferencji. 